Eskişehir Osmangazi Üniversitesi ïBF Dergisi

Aralık 2017, C. 12, S. 3, 81 - 102

Başvuru : 22.08.2017

Kabul : 23.10.2017

\title{
Türkiye Ekonomisinin Neo - Liberal Dönem Öncesindeki ve Sonrasındaki Sektörel Bağlantı Yapısının Girdi - Çıktı Yöntemiyle Analizi (1973 - 2012)
}

\begin{abstract}
Türkiye Ekonomisinin Neo - Liberal Dönem Öncesindeki ve Sonrasındaki Sektörel Bağlantı Yapısının Girdi - Çıktı Yöntemiyle Analizi (1973 - 2012)

Öz

Bu çalışmada, Neo - liberal politikalar açısından kritik bir öneme sahip 24 Ocak 1980 kararlarının Türkiye ekonomisinin sektörel bağlantı yapılarına etkileri girdi - çıktı yöntemiyle analiz edilmiştir. Bu analiz Tüik tarafından yayımlanan tüm girdi - çıktı tablolarının toplulaştırma yöntemiyle ortak bir sınıflamaya alınmasıyla yapılmıştır. Elde edilen bulgulara göre, 1980 öncesinde kilit sektör konumunda olmayan ve ihraç ettiği çıktı miktarından çok ara girdi ithal eden ana metal sanayiinin, 1980 sonrasında hem kilit sektör olduğu, hem de ithal ettiği ara girdiden çok çıktı ihraç ettiği görülmektedir. Ayrıca ihracat yeteneği olmayan ve ithal ara girdi kullanan inşaat sektörü 1973'den bu yana 2012'de ilk kez kilit sektör konumuna gelmiştir.
\end{abstract}

Anahtar Kelimeler: Girdi - Çıktı Yöntemi, Sektörel Bağlantılar, Neo - liberal Politikalar.
Analysis of the Sectoral Linkage Structure of the Turkish Economy Before and After the Neo - Liberal Period by Input - Output Method (1973 - 2012)

Abstract

In this study, the effects of 24 January 1980 decisions, which has a critical prescription for Neo - liberal policies, on the sectoral linkages in the Turkish economy were analyzed by input - output method. This analysis was carried out by taking all the input - output tables published by TURKSTAT into a common classification by the method of consolidation. According to the findings, it can be seen that the main metal industry, which was not a key sector before 1980 and imported more intermediate inputs than the output it has exported, appears to be both a key sector and exported more output from the imported intermediate after 1980. In addition, the construction sector, which has no export capability and uses imported intermediate inputs, has been the key sector for the first time since 1973.

Keywords: Input - Output Method, Sectoral Linkages, Neo - Liberal Policies.

\section{Giriş}

İktisatta statik genel denge analizleri ile ilgilenen başta Quesnay olmak üzere Fizyokratlardır (Özkazanç, 2006: 180). Girdi - çıktı analizinin temelini de F. Quesnay (1758)'in Tableau Economique adlı kitabı oluşturmaktadır. Öyle ki yazar bu kitabında bir ekonomideki üretim artışının toplumsal sınıflar arasındaki dağılımını ve tekrar üretim sürecine nasıl sokulduğunu analiz etmektedir (Bocutoğlu, 1990: 2 - 3). Genel denge kuramı daha sonra esaslı bir biçimde Lozan Okulu temsilcilerinden L. Walras ve V. Pareto tarafından geliştirilmiştir (Özkazanç, 2006: 180). V. Pareto tarafından geliştirilen ve daha sonra Pareto ölçütü olarak adlandırılan Pareto - optimalite ölçütü, objektif olarak ölçülebilen iktisadi etkinliğe atıfta bulunmaktadır. Buna göre Pareto optimalitesinin sağlanabilmesi için tüketiciler arasındaki mal dağılımında, firmalar arası girdi dağılımında ve girdilerin mallar arası dağılımında etkinliğin sağlanması gerekmektedir. Walras (1874) ise Elements of Pure Economics adlı kitabında tüm piyasalarda, tüm fiyat ve miktarların karşıııkı etkileşim içinde eşanlı olarak belirlendiğini belirtmektedir. Walras (1874), tüm piyasaların ve bu piyasalardaki satıcı (firma) ve alıcıların karşılıklı etkileşiminin tasviri için bir eş

\footnotetext{
${ }^{1}$ Arş. Gör., Muğla Sıtkı Koçman Üniversitesi, İktisadi ve İdari Bilimler Fakültesi, İktisat Bölümü, soneruysal@mu.edu.tr.
} 
anlı denklem sistemi kullanmıştır. Bu eş anlı denklem sisteminin çözümü malların ve üretim faktörlerinin denge fiyat ve miktarlarını vermektedir (Koutsoyiannis, 2004: 533, 575).

Her ne kadar firmalar arası üretim ilişkisi ile ilgili teorik temeller Fizyokrat görüşe kadar dayansa da, girdi - çıktı analizi bu adıyla ve modern anlamdaki uygulama şekliyle literatüre Leontief (1936) tarafından kazandırımıştır. Girdi - çıktı analizinin amacı kendi içerisinde homojen mallar ürettiği varsayılan sektörlerin birbirleriyle olan ilişkilerini ortaya koyarak bir ekonominin üretim yapısını belirlemektir.

Türkiye ekonomisi açısından girdi - çıktı yöntemi yardımıyla sektörel bağlantı yapıları ile ilgili literatüre bakıldığında, analizlerin genelde süreç bakımından dar kapsamlı olduğu görülmektedir. Öyle ki çalışmalar çoğunlukla Tüik tarafından yayımlanan en son veriler dikkate alınarak yapılmıştır. Bu nedenle Türkiye ekonomisi için uzun vadeli bir analiz, iktisat politikalarındaki değişikliğe bağı olarak sektörel bağlantı yapılarındaki değişikliğin ortaya koyulması açısından önem arz etmektedir. Bu çalışmada da TÜiK tarafından yayımlanan tüm girdi - çıktı tablosu verileri dikkate alınarak (1973 - 2012) sektörel bağlantı yapıları incelenmiş, böylece ekonomik politik açısından bir kırılma noktası olan 24 Ocak 1980 kararlarının sektörel bağlantı yapılarına nasıl etki ettiği analiz edilmiştir. Çalışmada öncelikle girdi - çıktı yöntemi ve sektörel bağlantı yapılarına ilişkin teorik bilgilere yer verilmiş, daha sonra bu konuyla ilgili Türkiye ekonomisi açısından gelişen literatür taranmış ve nihayetinde Türkiye ekonomisi için sektörel bağlantı yapılarının 1973 yılından günümüze nasıl bir seyir izlediği analiz edilmiştir.

\section{Teorik Çerçeve}

Çalışmanın bu kısmında öncelikle girdi - çıktı modelleri ile ilgili teorik bir altyapı oluşturulacak ve daha sonra girdi - çıktı modellerinden hareketle sektörler arasındaki bağlantı yapılarından bahsedilecektir.

\subsection{Temel Girdi - Çıktı Yöntemi}

Girdi - çıktı analizinin temelini firmaların üretim sürecinde diğer firmaların çıktılarını ara girdi olarak kullanmaları ve kendi çıktılarının da diğer firmalar tarafından ara girdi olarak kullanılması oluşturmaktadır. Nitekim Evans ve Hoffenberg (1954) girdi - çıktı yönteminin hem bir ekonomi içerisindeki birbiriyle bağlantılı faaliyetleri sorgulayan, hem de bu faaliyetlerin neden - sonuç ilişkilerini ortaya koyarak iktisadi sorunların çözümünde rol oynayan bir yapıda olduğunu belirtmektedir (Aydın, 2001: 4). Bu aşamada öncelikle girdi - çıktı modelleri matematiksel olarak ifade edilecek ve daha sonra sektörel bağlantı yapılarından bahsedilecektir.

Bir ekonomide $n$ tane sektör olduğunu varsayalım. $z_{i j}$ bir $i$ sektöründen bir $j$ sektörüne yapılan mal ve hizmet transferlerinin parasal değerini ve $f_{i}{ }^{2}$ bir $i$ sektörünün malına olan nihai talebi göstermek üzere; bir i sektörünün toplam üretim miktarı $\left(x_{i}\right)$ aşağıdaki şekilde hesaplanabilir (Miller ve Blair, 2009: $11-12$ ).

$$
x_{i}=z_{i 1}+\cdots+z_{i j}+\cdots+z_{i n}+f_{i}=\sum_{j=1}^{n} z_{i j}+f_{i}
$$

Yukarıdaki (1) numaralı denklemde $i$ sektörünün toplam çıktısı gösterilmektedir. Ekonomideki $n$ sektörün tamamı dikkate alındığında ve değişkenler matris formunda yazıldığında aşağıdaki (2) numaralı eşitliklere ulaşılacaktır.

\footnotetext{
${ }^{2}$ Bir i sektörünün çıktısı başka bir sektör tarafından talep edilebileceği gibi endüstri dışından, nihai tüketiciler tarafından da talep edilebilir. Bu nedenle modeldeki nihai talepten kasıt, hane halklarının tüketim harcamaları, kamu harcamaları ya da yatırım harcamaları gibi nedenlerle talep edilen malların parasal değeridir.
} 


$$
x=\left[\begin{array}{c}
x_{1} \\
\vdots \\
x_{n}
\end{array}\right] \quad Z=\left[\begin{array}{ccc}
z_{11} & \ldots & z_{1 n} \\
\vdots & \ddots & \vdots \\
z_{n 1} & \ldots & z_{n n}
\end{array}\right] \quad f=\left[\begin{array}{c}
f_{1} \\
\vdots \\
f_{n}
\end{array}\right]
$$

Bu aşamada girdi - çıktı modelleri ile ilgili önemli bir varsayıma dikkat çekmek gerekmektedir. Buna göre herhangi bir $j$ sektörünün bir $i$ sektörü çıktısına olan ara girdi talebi, $j$ sektörünün kendi üretim miktarının doğrusal bir fonksiyonudur (Aydın, 2001: 15). Böylece teknoloji katsayısı olarak adlandırılan $a_{i j}$ aşağıdaki gibi hesaplanmaktadır.

$$
a_{i j}=\frac{z_{i j}}{x_{j}}
$$

Yukarıdaki $a_{i j}$ oranı, dolaysız ara girdi katsayısı olarak da adlandırılmaktadır. Bu katsayılar, ilgili sektörün çıktısındaki bir birimlik bir değişmeye bağı olarak diğer tüm sektörlerdeki dolaysız etkileri göstermektedir (Atan, 2011: 64). Yukarıdaki (1) numaralı denklem, nihai talep yalnız bırakılacak ve $z_{i j}=a_{i j} x_{j}$ yazılacak şekilde $n$ sektör için yeniden çözümlenirse aşağıdaki eşitlik elde edilecektir (Hawkins vd., 2007: 1025).

$$
\begin{aligned}
& f_{1}=\left(1-a_{11}\right) x_{1}-a_{12} x_{2}-\cdots-a_{1 n} x_{n} \\
& f_{2}=-a_{21}+\left(1-a_{22}\right) x_{2}-\cdots-a_{2 n} x_{n} \\
& \vdots \\
& f_{n}=-a_{n 1} x_{1}-a_{n 2} x_{2}-\cdots-\left(1-a_{n n}\right) x_{n}
\end{aligned}
$$

Yukarıdaki (4) numaralı eşitlikte yer alan denklem sistemi matris formunda $f=(I-A) x$ şeklinde ifade edilebilir. Bu ifadede $f$ nihai talep vektörünü, $I$ birim matrisi, A teknoloji katsayılarını $\left(a_{i j}\right)$ içeren matrisi, $x$ ise her bir sektörün çıktı vektörünü göstermektedir. Belirli bir nihai talep seviyesi için sektörlerin çıktı düzeyleri ise matris formunda aşağıdaki şekilde hesaplanmaktadır (Hawkins vd., 2007: 1025).

$$
x=(I-A)^{-1} f
$$

Yukarıdaki (5) numaralı eşitlikteki $(I-A)^{-1}$ ifadesi Leontief ters matrisi olarak adlandırılmaktadır. Leontief ters matrisi, nihai talepteki değişikliklere bağlı olarak sektörlerin çıktısının ne ölçüde değişeceğini göstermektedir (Tanaka, 2011: 53). Bu aşamada bağlantı analizleri devreye girmektedir. Peki bağlantı analizlerinden kasıt nedir? Bu aşamada yukarıda bahsi geçen Leontief ters matrisinin iktisadi yorumuna açıklık getirmek yararlı olacaktır. Örneğin bir $i$ sektörünün çıktısına yönelik nihai talepte bir artış olduğunda, sektör bu talebi karşılamak için çıktısını artırmak isteyecektir. Ancak $i$ sektörü çıktısını artırmak için diğer sektörlerden de girdi talep edecek ve o sektörler de kendilerine olan talep artışını karşılamak için çıktısını artırmak durumunda kalacaktır. Nihayetinde bir sektördeki talep artışı yalnızca doğrudan ilgili sektörü değil, diğer sektörleri de etkileyerek dolaylı olarak çıktı artışına yol açacaktır (Öney, 1980: 134 - 135).

Bağlantı analizleri, sektörler arasındaki bağlantı yapılarının belirlenmesi açısından önem arz etmektedir. Nitekim Reis ve Rua (2006), girdi - çıktı analizinin temelinin Leontief (1936) tarafından atılmasına rağmen, Rasmussen (1956) ve Chenery ve Watanabe (1958)'in sektörler arasındaki bağ yapılarının analizine yönelik çalışmalarından sonra girdi - çıktı analizleri ile ilgili teorik ve ampirik bazda önemli bir literatür geliştiğini belirtmektedir.

\subsection{Illeri ve Geri Bağlantılar}

Doğrudan geri bağlantıları ilk inceleyen Chenery ve Watanabe (1958)'dir. Buna göre bir sektörün bir birimlik çıktı üretebilmek için diğer sektörlerden ne ölçüde çıktı talep ettiği doğrudan geri bağlantı olarak adlandırılmaktadır. Doğrudan geri bağlantı katsayısı (5) numaralı eşitlikte 
belirtilen $A$ teknoloji katsayıları matrisinin her bir sütun elemanlarının toplamıdır ve aşağıdaki şekilde ifade edilmektedir (Temurshoev, 2004: 11).

$$
B L_{j}^{C W}=\sum_{i=1}^{n} \frac{z_{i j}}{x_{j}}=\sum_{i=1}^{n} a_{i j}
$$

Doğrudan geri bağlantı yukarıdaki gibi hesaplanıyorken, doğrudan ileri bağlantı da benzer yöntemle hesaplanabilir. Buna göre bir sektörün çıktısının ne kadarının diğer sektörler tarafından girdi olarak kullanıldığı ileri bağlantı olarak adlandırımaktadır ve doğrudan ileri bağlantı katsayısı Chenery ve Watanabe (1958) tarafından geliştirilen yöntem kullanılarak aşağıdaki gibi hesaplanmaktadır.

$$
F L_{i}^{C W}=\sum_{j=1}^{n} \frac{z_{i j}}{x_{i}}=\sum_{j=1}^{n} a_{i j}
$$

Ancak bu yöntem çalışmanın önceki kısmında da bahsedilen dolaylı etkilerin ölçümü noktasında eksikliğe sahiptir. Örneğin (6) numaralı eşitlikle hesaplanacak bir geri bağlantı yalnızca o sektörün çıktısındaki bir değişim için diğer sektörlerin ne kadarlık çıktı üretmesi gerektiğini, yani doğrudan etkiyi ölçmektedir. Bu nedenle bir $j$ sektörünün çıktısındaki değişmenin, o sektöre girdi sağlayan sektörlerde yaratacağı etkinin de diğer sektörler üzerinde ne gibi etkiler yaratabileceğinin, yani dolaylı bağlantı etkilerinin de dikkate alınması gerekmektedir. Bunun için de Rasmussen (1956) tarafından geliştirilen yöntem kullanılmaktadır.

Rasmussen (1956) hem doğrudan hem de dolaylı etkileri hesaba katmak için (5) numaralı eşitlikteki Leontief ters matrisini kullanmıştır. Buna göre Leontief ters matrisindeki $\left((I-A)^{-1}\right)$ her bir eleman $r_{i j}$ ile gösterilmek üzere toplam geri bağlantı katsayısı aşağıdaki şekilde hesaplanmaktadır (Temurshoev, 2004: 13).

$$
B L_{j}^{R}=\sum_{i=1}^{n} r_{i j}
$$

Toplam ileri bağlantı katsayısı da, benzer bir biçimde Leontief ters matrisindeki her bir satırın elemanları toplamı şeklinde aşağıdaki gibi hesaplanmaktadır (Temurshoev, 2004: 13).

$$
F L_{i}^{R}=\sum_{j=1}^{n} r_{i j}
$$

Farklı özellikteki sektörler arasındaki geri ve ileri bağlantı katsayıları arasında bir kıyaslama yapabilmek için toplam bağlantı katsayılarının normalleştirilmesi gerekmektedir. Toplam geri ve ileri bağlantı katsayısının normalleştirilmesi ise sırasıyla aşağıdaki gibi yapılmaktadır (McGilvray, 1977: 50; Drejer, 2002: 5).

$$
\begin{aligned}
B L_{j}^{R *} & =\frac{1}{n} \sum_{i=1}^{n} r_{i j} / \frac{1}{n^{2}} \sum_{i j=1}^{n} r_{i j} \\
F L_{i}^{R *} & =\frac{1}{n} \sum_{j=1}^{n} r_{i j} / \frac{1}{n^{2}} \sum_{i j=1}^{n} r_{i j}
\end{aligned}
$$

Buna göre $B L_{j}^{R *}>1$ ise $j$ sektörünün toplam geri bağlantı etkisi diğer sektörlere göre yüksek olacaktır. Aynı şekilde $F L_{i}^{R *}>1$ ise de $i$ sektörünün toplam ileri bağlantı etkisi diğer sektörlere göre yüksek olacaktır (McGilvray, 1977: 50 - 51).

Her ne kadar (10) ve (11) numaralı denklemlerle elde edilecek sonuçlar sektörler arası bağlantı yapıları hakkında önemli göstergeler sunsa da, sektörlerin ekonomi içerisindeki göreli ağırlıklarını dikkate almamaktadır. Örneğin bir sektörün toplam ileri ve geri bağlantıları yüksek olsa bile, o sektörün ekonomi içerisindeki payı düşük olabilir. Bu nedenle bir sektörün bağlantı yapısı incelenirken, o sektörün çıktısına olan nihai talebin ya da o sektörün toplam çıktısının ekonomi içerisindeki payının da dikkate alınması gerekmektedir. Nitekim Drejer (2002), sektörlerin göreli 
öneminin nihai talep ya da sektörel çıktı olmak üzere iki farklı şekilde dikkate alınabileceğini belirtmektedir. Bunlardan birincisi bir $i$ sektörüne olan nihai talebin, tüm sektörlere olan nihai talepler toplamına oranı şeklinde hesaplanmaktadır $\left(\alpha_{i}=f_{i} / \sum_{i}\right)$. İkincisi ise bir sektörün toplam çıktısının tüm sektörlerin toplam çıktısına oranı şeklinde hesaplanmaktadır $\left(\beta_{i}=\right.$ $\sum_{j}\left(x_{i j}+f_{i j}\right) / \sum_{i j}\left(x_{i j}+f_{i j}\right)$. Drejer (2002) ağırlıklandırma işlemi için bu iki yöntemden herhangi birisinin kullanılabileceğini belirtmektedir. Böyle bir durumda ağırlıklandırılmış ve normalleştirilmiş geri ve ileri bağlantı katsayıları sırasıyla aşağıdaki gibi hesaplanmaktadır $\left(w_{i}=\right.$ $\alpha_{i}$ ya da $\beta_{i}$ ).

$$
\begin{aligned}
& B L_{j}^{W}={ }^{\frac{1}{n} \sum_{i=1}^{n} w_{i} r_{i j} / \frac{1}{n^{2}} \sum_{i j=1}^{n} w_{i} r_{i j}} \\
& F L_{i}^{W}={ }^{\frac{1}{n} \sum_{j=1}^{n} w_{J} r_{i j} / \frac{1}{n^{2}} \sum_{i j=1}^{n} w_{J} r_{i j}}
\end{aligned}
$$

Bu çalışmada bir sektörün çıktısına olan nihai talebin toplam nihai talep içerisindeki payı dikkate alınarak ağılıklandırma yapılmıştır $\left(w_{i}=\alpha_{i}\right)$. Örneğin bir sektörün toplam bağlantı yapıları güçlü ve o sektörün çıktısına olan nihai talep de yüksekse, o sektörün ağırlıklı toplam bağlantılarının diğer sektörlere göre daha güçlü olduğu söylenebilir. Ağırlıklı toplam bağlantı katsayıları için de toplam bağlantı katsayılarındaki gibi bir yorum yapılabilir. Burada da (12) ve (13) numaralı denklemlerde belirtilen ağırıklı toplam geri ve ileri bağlantı katsayılarının birden büyük olması $\left(B L_{j}^{W}, F L_{i}^{W}>1\right)$, ilgili sektörün diğer sektörlere göre göreli öneme sahip olduğu anlamına gelecektir.

Sektörel bağlantı yapılarından hareketle bir ekonomideki yatırımların hangi alanlara yönlendirilmesi gerektiği ile ilgili, yatırım öncelikli kilit sektör adı altında dörtlü bir sınıflandırmanın literatürde yaygın olarak yer aldığı görülmektedir. Bir sektör diğer sektörlerin çıktısından ne kadar fazla talep ediyor ve bu sektörün çıktısı da diğer sektörleri ne kadar çok besliyorsa (yüksek geri ve yüksek ileri bağlantı), o sektör yatırım öncelikli kilit sektör olacaktır ve kıt kaynaklar bu sektörlere yönlendirilmelidir. Bu nedenle alışmanın bundan sonraki kısımlarında kilit sektör olarak ifade edilen bir sektörün hem geri hem de ileri bağlantısının 1,00 değerinin üzerinde olduğu anlaşılmalıdır. Bir sektörün diğer sektörleri besleme yeteneği düşük olsa bile, en azından diğer sektörlerin çıktısını daha fazla talep etmesi beklenir (yüksek geri, düşük ileri bağlantı) ki bir ekonomide yatırım önceliği ikinci olarak bu sektörlere verilmelidir. Eğer bir sektör diğer sektörler tarafından çok beslenmiyorsa, bu sektörün en azından diğer sektörleri göreli olarak daha fazla beslemesi beklenir (düşük geri, yüksek ileri bağlantı) ki yatırım önceliği üçüncü olarak bu sektörlere verilmelidir. Ekonomideki kıt kaynakların en son ise diğer sektörleri besleme ve diğer sektörlerden beslenme yeteneği düşük olan (düşük geri ve düşük ileri bağlantı) sektörlere yönlendirilmesi gerekmektedir ${ }^{3}$.

Çalışmanın bundan sonraki kısmında sektörel bağlantı yapıları ile ilgili gelişen yerli ve yabancı literatüre yer verilecektir. Özellikle Türkiye ekonomisi için yapılan çalışmaların kapsamı,

\footnotetext{
${ }^{3}$ Söz konusu dörtlü sınıflama ile ilgili literatürün Rasmussen (1956) ve Hirschman (1958)'in sektörel bağlantı yapıları ile ilgili görüşlerinden yola çıkılarak geliştirildiği görülmektedir. Yatırım öncelikli kilit sektörlerle ilgili ayrıntılı bilgi için Aydoğuş (1999), Gurgul ve Majdosz (2005), Reis ve Rua (2006) ve Humavindu ve Stage (2013)'e bakılabilir.
} 
bu çalışmada kullanılan yöntemin de gerekçesini oluşturduğundan yerli literatüre ilişkin analizler daha geniş tutulmuştur.

\section{Sektörel Bağlantı Yapılarına İlişkin Literatür Taraması}

Çalışmanın önceki kısımlarında, girdi - çıktı yönteminin literatüre Leontief (1936) tarafından kazandırıldığından ve özellikle Rasmussen (1956) ve Chenery ve Watanabe (1958)'in sektörel bağlantı yapılarına ilişkin çalışmalarından sonra bu konuyla ilgili literatürün hızla geliştiğinden bahsedilmişti. Bu nedenle literatür taramasına bu iki çalışmadan başlanacak ve yabancı literatür tamamlandıktan sonra literatürdeki Türkiye ekonomisi ile ilgili çalışmalara yer verilecektir.

Rasmussen (1956) Studies in Inter - Sectoral Relations adlı doktora tezinde, temelde fiyat değişimlerinin sektörlerarası ilişkileri nasıl etkilediğini analiz etmektedir. Ancak bu çalışmada Rasmussen'in kullandığı dağılım gücü endeksi ve dağılım duyarlıığı endeksi ilerleyen dönemlerde sırasıyla geri ve ileri bağlantı etkilerini ölçmek için kullanıldığından literatürde önemli bir yere sahiptir (Drejer, 2002: 4 -5). Chenery ve Watanabe (1958) ise ABD, Japonya, Norveç ve Italya ekonomilerinin üretim yapılarını karşılaştırdığı çalışmalarında, bu çalışmanın önceki kısımlarında (7) ve (8) numaralı denklemlerle belirtilen doğrudan bağlantıları ilk kez kullanmışlardır. Öyle ki doğrudan geri ve ileri bağlantıların hesabında kullanılan bu yöntem literatürde Chenery-Watanabe yöntemi olarak adlandırılmaktadır.

West ve Brown (2003), 1976 - 1994 yılları arasındaki altı yıla ait verileri kullanarak Tayvan ekonomisi için kilit sektör analizi yapmışlardır. Elde edilen bulgulara göre tarım sektörü Tayvan ekonomisi için kilit öneme sahiptir. Bunun yanında imalat sanayinde yapısal bir değişim söz konusudur. Öyle ki imalat sanayindeki geri bağlantı katsayısı 1,25 - 1,35 arasında değişirken, ileri bağlantı katsayısı yalnızca 1976 ve 1981 yıllarında 1,00 seviyesinin üzerine çıkabilmiştir.

Andreosso-O'Callaghan ve Yue (2004), Çin ekonomisindeki kilit sektör analizini 1987 - 1997 yılları arasındaki beş adet zaman serisini ve Chenery - Watanabe, Rasmussen, Dietzenbacher ve van der Linden ve Pure-linkage olmak üzere dört farklı yöntemi kullanarak analiz etmişlerdir. Elde edilen bulgulara göre Çin ekonomisi için kilit sektör analizleri dört farklı yöntem için önemli farklılıklar içermektedir. Örneğin Chenery - Watanabe yöntemine göre Çin ekonomisi için hem ileri hem de geri bağlantı etkisi yüksek (kilit) sektörler petrol ürünleri, kimyasal ürünler, inşaat malzemeleri, ana metaller ve metal ürünleri üretimi iken, Dietzenbacher ve van der Linden yönteminde yalnızca aşçılık sektörü kilit konumdadır.

Gersak ve Muhaj (2016) tarafından Slovenya ekonomisi için yapılan ve 2005, 2009 ve 2010 yıllarını kapsayan girdi - çıktı analizinde; her üç yıl için de basım ve kayıt işleri, kanalizasyon ve atık toplama hizmetleri ile sanitasyon ve benzeri hizmetler, elektrik enerjisi, gaz, buhar ve sıcak su üretimi, inşaat, toptan ticaret ve posta ve telekominasyon sektörlerinde ileri ve geri bağlantı katsayılarının yüksek çıktığı belirtilmektedir.

Türkiye ekonomisine yönelik yapılan sektörel bağlantı analizleri ile ilgili literatür taramasına Aydın (2001) tarafından yapılan çalışma ile başlanacaktır. Aydın (2001), 1973 - 1990 arası dönemdeki sektörel bağlantı yapısını TÜík tarafından yayımlanan 1973, 1979, 1985 ve 1990 girdi - çıktı tablolarını kullanarak incelemiştir. Elde edilen bulgulara göre kâğıt ürünleri ile basım ve yayım, metal ana sanayi ve ulaşım araçları sanayii analize dâhil edilen tüm yıllar için yüksek geri ve yüksek ileri bağlantı katsayılarına sahip olduğundan kilit konumdadır. Bunun yanında kimya sanayi 1973 yılı itibariyle düşük geri ve düşük ileri bağlantı katsayısı ile stratejik açıdan en az öneme sahip bir yapıdayken, 1979 - 1990 arasında kilit sektör konumuna gelmiştir. Öyle ki 
kimya sanayi için geri ve ileri bağlantılar 1979 'dan itibaren 1,00 değerinin üzerine çıkmıştır. Kauçuk ve plastik sanayiinde de benzer bir değişim söz konusudur. 1973 - 1985 arasında kilit sektör konumunda olan kauçuk ve plastik sanayii sektörü 1990 yılı itibariyle geri bağlantı etkisindeki göreli önemini yitirmiştir.

Çondur ve Evlimoğlu (2007), madencilik sektörünün alt sektörleri itibariyle bağlantı yapıla-

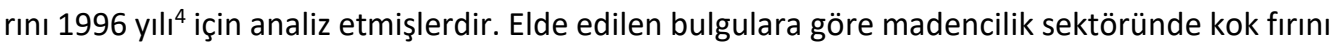
ve rafine edilmiş petrol ürünleri imalatı en yüksek geri $(0,872)$ ve ileri bağlantı $(0,928)$ katsayısı değerine sahiptir.

Ersungur ve Kızıltan (2008), Aydın (2001)'in çalışmasına benzer bir biçimde, çalışmanın yapıldığı yıla kadar yayımlanan tüm girdi - çıktı tablolarını $(1973,1979,1985,1990,1996,1998)$ kullanarak sektörel bağlantı analizi yapmışlardır. Ancak bağlantı yapısının basit üretim çarpanı (yapısal bağınlaşma) adı altında yalnızca geri bağlantı etkisini gösterecek şekilde analiz edildiği görülmektedir. Elde edilen bulgulara göre 1980 öncesinde (1973-1979) üretim çarpanı açısından en duyarlı ilk sekiz sektör; tarım, hayvancılık, dokuma sanayi, karayolu taşıması, bina inşaatı, mezbaha ürünleri üretimi, diğer besin maddeleri üretimi ve demir-çelik ana sanayiidir. 1980 sonrasında ise yapısal bağınlaşmanın yüksek olduğu sektörler daha çok sanayi sektörünün alt dallarıdır.

Atan (2011), 2002 yılı girdi - çıktı tablosunu kullanarak sektörel bağlantı analizi yapmıştır. Söz konusu çalışmada ara girdilerin hem dolaysız ve toplam, hem de genel, yurtiçi üretim ve ithal olmasına göre hesaba katıldığı görülmektedir. Elde edilen bulgulara göre imalat sanayi sektörünün her üç kategoride; elektrik enerjisi, gaz, buhar ve su sektörü genel ve yurtiçi üretilen dolaysız ara girdilerde; inşaat ve ulaştırma, depolama ve haberleşme hizmetleri sektörü ise sadece yurtiçi üretimle elde edilen dolaysız ara girdiler kategorisinde kilit sektör konumundadır.

Ayaş (2016), hizmetler sektörüne ilişkin bağlantı yapılarını WIOD (World Input Output Database) verilerini kullanarak 1995 - 2001 yılları için analiz etmiştir ${ }^{5}$. Elde edilen bulgulara göre hizmetler sektörüne ait alt dalların tamamında toplam geri bağlantı etkileri birden yüksektir. Özellikle elektrik, gaz ve su faaliyetlerindeki geri bağlantı etkisindeki artış göze çarpmaktadır. Bunun yanında inşaat sektörü ile otel ve restoran sektörüne ilişkin geri bağlantı etkilerinin de diğer hizmet sektörlerine göre yüksek olduğu görülmektedir.

Uğurlu ve Tuncer (2017), sanayi ve hizmetler sektörünün Türkiye ekonomisinin büyümesine ve istihdamına olan etkisini 1995 ve 2001 yıllarına ait WIOD girdi - çıktı tablolarını kullanarak incelemişlerdir. Buna göre 2011 yılında tekstil ve tekstil ürünleri, deri ve deri ürünleri, ağaç ürünleri, kağıt ve kağıt ürünleri, kok kömürü ve rafine edilmiş petrol ürünleri, kimyasal ürünler,

\footnotetext{
${ }^{4}$ Türkiye ekonomisi için 2004 yılı itibariyle sekiz adet girdi - çıktı tablosunun hazırlanmıştır. Bunların ikisi, 1959 ve 1963 yıllarında Devlet Planlama Teşkilatı (DPT) tarafından; kalan altı tanesi ise 1968, 1973, 1979, 1985, 1990 ve 1996 yıllarında olmak üzere Devlet İstatistik Enstitüsü (DiE) tarafından gerçekleştirilmiştir (Eren, 2004: 29). Ancak DPT tarafından yapılan her iki çalışma ile DíE tarafından 1968 ve 1996 yılları için yapılan çalışmalara elektronik ortamda ulaşma imkânının olmaması nedeniyle literatürde bu verilerin kullanıldığı çalışmaların çok sınırlı sayıda olduğu görülmektedir. Daha sonra ismi Türkiye İstatistik Kurumu (TÜiK) olarak değiştirilen DiE 1998, 2002 ve 2012 yılları için de girdi - çıktı tablosu hazırlamıştır. Bunlar da dikkate alındığında 2017 yılı itibariyle Türkiye ekonomisi için toplamda on adet girdi - çıktı tablosunun hazırlanmış olduğu görülmektedir.

${ }^{5}$ WIOD (World Input Output Database), ülkelerin girdi - çıktı tablolarına ilişkin verileri her yıl yayımlamaktadır. Ancak bu veriler en fazla 1995 yıına kadar uzanmaktadır. 24 Ocak 1980 kararlarının Türkiye'deki sektörel bağlantı yapılarına olan etkisi, WIOD verileri ile analiz edilemeyeceğinden bu çalışmada TÜik verilerinden yararlanılmıştır. WIOD ile ilgili ayrıntılı bilgi için http://www.wiod.org/home web sayfası ziyaret edilebilir.
} 
kauçuk ve plastik ürünler, metalik olmayan mineral ürünler, elektrik, gaz ve sıcak su faaliyetleri ile seyahat acenteliği sektörleri kilit sektör durumundadır.

Türkiye ekonomisi ile ilgili literatüre bakıldığında, TÜik verileri baz alınarak yapılan çalışmaların çoğunlukla bir ya da iki yıllık verileri kapsadığı, uzun dönemli yapılan çalışmaların ise aynı sektör sınıflamasına sahip yılları kapsadığı, farklı sektör sınıflamalı olan yılların dahil edildiği çaış̧maların ise toplulaştırma yapılmadan, her bir farklı sektör sınıflamasının ayrı ayrı dikkate alındığı görülmektedir. Bu durum, hem Türkiye ekonomisi için kritik öneme sahip olan olayların sektörel bağlantı yapısına olan etkisinin analizini, hem de aynı sektörlerin bağlantı yapılarının yıllar içerisinde nasıl bir değişim gösterdiğinin analizini güçleştirmektedir. Örneğin Aydın (2001) tarafından yapılan çalışma 24 Ocak 1980 kararlarının bağlantı yapılarına olan etkisinin analizi açısından önemli bir yere sahiptir; ancak bu çalışmadaki önemli bir avantaj Tüik verilerinin çaıı̧̧ma kapsamındaki yıllar için aynı sektör sınıflamalı olmasıdır. Nitekim Ersungur ve Kızıltan (2008) tarafından yapılan çalışmada dikkate alınan yıllara ait girdi - çıktı tabloları iki farklı sektör sınıflaması içerdiğinden yazarlar her bir sınıflamayı kendi içerisinde ayrı ayrı değerlendirmişlerdir. Bütün bu nedenlerden dolayı, Türkiye ekonomisine ait tüm girdi - çıktı tablolarının aynı sınıflama içerisinde değerlendirebilmesi için ortak bir sınıflama üzerinden toplulaştırma yapılması gerekmektedir. Böylece uzun dönemli analiz de yapılabilecektir. Bu nedenle, bu çalışmada toplulaştırma ile ortak bir sınıflama baz alınmıştır. Çalışmanın bundan sonraki kısmında bu toplulaştırmaya ve uygulama sonuçlarına ilişkin bilgilere yer verilecektir.

\section{Bulgular}

Türkiye, ekonomik politik açısından iki uç noktada yoğunlaşan ithal ikameci ve ihracata dayalı büyüme stratejilerinde kırılma noktasını 1980'li yılların başlarında yaşamıştır. 1980 yılı öncesinde beşer yıllık kalkınma planları ile temelde ithal ikameci politikalar uygulayan Türkiye, 24 Ocak 1980 kararları ile birlikte ihracata dayalı bir model benimsemiştir. İhracata dayalı büyüme stratejileri de temelde birbirini tamamlayan iki unsurdan oluşmaktadır. Bunlardan birincisi ticaretin serbestleştirilmesi, ikincisi ise finansal serbestleşmedir. 24 Ocak 1980 kararları ile birlikte uygulamaya geçirilen ihracatı teşvik etmeye, ithalatı kolaylaştırmaya ve faiz oranlarını yükseltmeye yönelik politikalar da birbirini tamamlayan bu iki unsura yöneliktir.

Çalışmanın bu kısmında 1980 öncesi ve sonrası dönemde uygulanan politikaların sektörler arasındaki bağlantı yapılarına olan etkileri incelenecektir. Ancak bu analizin farklı dönemleri kapsayacak şekilde yapılabilmesi için girdi - çıktı tablolarındaki sektör sınıflamalarının aynı olması gerekir. Tüik verilerine bakıldığında ise 1973, 1979, 1985 ve 1990 yılları ile 1998, 2002 ve 2012 yılları ayrı ayrı olmak üzere toplamda dört farklı sınıflamalı girdi - çıktı tabloları olduğu görülmektedir. Bu nedenle farklı sınıflamalı girdi - çıktı tabloları arasında karşılaştırma yapılabilmesi için de toplulaştırma yapılması gerekmektedir. Dönemler arasında karşılaştırma yapabilmek adına Tüik girdi - çıktı tabloları Ek Tablo 1'deki gibi toplulaştırılmış ve bağlantı analizleri bu toplulaştırma baz alınarak yeniden oluşturulan girdi - çıktı tabloları kullanılarak yapılmıştır. Ek Tablo 1'den de görülebileceği üzere analizin yapılacağı tüm yıllar için her bir girdi - çıktı tablosu toplam 24 sektöre indirgenmiştir. Söz konusu toplulaştırma işlemi bire bir olmamakla birlikte, temelde Avrupa Ekonomik Topluluğunda Faaliyete Göre Ürünlerin İstatistiki Sınıflaması (CPA-2008) baz alınarak yapılmıştır. Örneğin 1998 yılına ait girdi - çıktı tablosundaki 01, 02, 03 ve 04 numaralı sektörler tarım, ormancılık ve balıkçılıkla ilgili sektörleri kapsadığı için toplulaştırılmıştır ve bu toplulaştırma 2012 yılı için ilgili girdi - çıktı tablosundaki A01, A02 ve A03 numaralı sektörleri kapsamaktadır. 
Türkiye ekonomisi için (12) ve (13) numaralı denklemlerle belirtilen ağırlıklı geri ve ileri bağlantı katsayıları 1973 - 2012 yılları arasındaki TüiK tarafından yayınlanan 1973, 1978, 1985, 1990, 1998, 2002 ve 2012 yıllarına ait yedi adet girdi - çıktı tablosunun Ek Tablo 1'de belirtilen toplulaştırma baz alınarak yeniden oluşturulmasıyla hesaplanmıştır. Bu aşamada önemli bir noktaya dikkat çekmek gerekmektedir. Sektörel bağlantı analizlerinin yurtiçi üretim - ithal ara girdi ayrıştırması yapılarak analiz edilmesi daha sağlıklıdır. Ancak Tüik verilerine bakıldığında yalnızca 1998, 2002 ve 2012 yıllarına ait girdi - çıktı tabloları için yurtiçi üretim - ithal ara girdi ayrışmasının var olduğu görülmektedir. Ancak bu çalışmanın amacı uzun dönemli bir analiz ortaya koymak olduğundan, tüm veriler için sektörel bazda çıktı ihracatının ara girdi ithalatını karşılama oranlarının $\left(e_{i}\right)$ dikkate alınmasının, en azından sektörlerin ne ölçüde ithal girdi kullandığının ve çıktılarının ne ölçüde ihraç edildiğinin analizi açısından yararlı olacağı düşünülmektedir. Aşağıdaki (14) numaralı eşitlikte sektörel bazda çıktı ihracatının ara girdi ithalatını karşılama oranı $\left(e_{i}\right)$ matematiksel olarak gösterilmektedir. Örneğin bir sektör yüksek geri ve yüksek ileri bağlantı ile kilit sektör konumunda olsa bile, ithal ettiği ara girdi miktarı ihraç ettiği çıktı miktarından büyük olduğu sürece, yatırımların bu sektöre aktarılması o ekonominin dışa bağımıılığını ve kırılganlığını artıran bir unsur olacaktır. Bu nedenle analizin daha sağııklı olabilmesi adına Tablo 1, Ek Tablo 1 ve Ek Tablo 2'de sektörel bağlantı katsayılarının yanında $e_{i}$ oranlarına da yer verilmiştir.

$$
e_{i}=\sum_{j=1}^{n} X_{i} / M_{i j}
$$

Ek Tablo 1 ve Ek Tablo 2 ile Tablo 1'den de görüldüğü üzere tarım, ormancılık ve balıkçılık sektöründe önemli yapısal değişimler söz konusudur. 1980 öncesinde geri ve ileri bağlantı katsayıları 4,00-4,50; $e_{i}$ oranları da 3,50 - 5,00 aralığında değişmektedir. Bu durum ilgili sektörün o dönemde ekonomideki en kilit sektör olduğunu, üstelik ihraç ettiği çıktının kullandığı ithal ara girdisinin çok çok üzerinde olduğunu göstermektedir. Tarım, balıkçılık ve ormancılık sektörü için 1980 sonrasında bağlantı katsayıları azalsa da, hala 1,00 değerinin üzerindedir ve bu sektör Türkiye ekonomisi için hala kilit sektör olma özelliğini korumaktadır. Ancak 1980 sonrası söz konusu sektörün rekabet baskısına girdiği görülmektedir. Öyle ki 1990 ve 2002 yıllarında bu sektörün kullandığı ithal ara girdi, ihraç ettiği çıktının üzerine çıkmıştır. 1985, 1998 ve 2012 yıllarında ise ihraç edilen çıktı, kullanılan ithal ara girdinin üzerine çıkmış olmasına rağmen, bu oran 1980 öncesi kadar yüksek değildir.

Madencilik ve taş ocakçılığı sektörü yalnızca 1985 yılında yüksek geri ve ileri bağlantı katsayısına sahip bir (kilit) sektördür. Ancak 1985 yılı itibariyle sektör ihraç ettiğinin çok üzerinde ara girdi ithal etmektedir. 2012 yılı itibariyle söz konusu sektörün bağlantı katsayıları çok düşüktür; ancak $e_{i}$ oranı 1980 sonrası ilk kez 1,00 değerinin üzerine çıkmıştır. Madencilik ve taş ocakçılığı sektörü kilit sektör konumunda olmasa da, ithal ettiğinden fazla ürün ihraç etmektedir. 
Eskişehir Osmangazi Üniversitesi iißBF Dergisi

Tablo 1: Toplam Ağırlıklandırılmış Geri $\left(B L_{j}^{W}\right)$ ve Ileri $\left(F L_{j}^{W}\right)$ Bağlantı Katsayıları Yüksek Olan Sektörler ve Bu Sektörlere Ait Çıktı Ihracatının Ara Malı Ithalatını Karşılama Oranları $\left(e_{i}\right)$

\begin{tabular}{|c|c|c|c|c|c|c|c|c|}
\hline SEKTÖRLER & & 1973 & 1979 & 1985 & 1990 & 1998 & 2002 & 2012 \\
\hline \multirow{3}{*}{$\begin{array}{l}\text { Tarım, Ormancılık ve Balık- } \\
\text { çılık Ürünleri }\end{array}$} & $B L_{j}^{W}$ & 4,555 & 4,297 & 2,771 & 2,918 & 2,286 & 1,771 & 1,384 \\
\hline & $F L_{j}^{W}$ & 4,679 & 4,040 & 2,535 & 2,628 & 2,187 & 1,707 & 1,516 \\
\hline & $e_{i}$ & 3,608 & 5,806 & 1,309 & 0,963 & 1,027 & 0,946 & 1,059 \\
\hline \multirow{3}{*}{$\begin{array}{l}\text { Toptan ve Perakende Tica- } \\
\text { ret }\end{array}$} & $B L_{j}^{W}$ & 1,808 & 2,005 & 2,006 & 2,066 & 2,113 & 2,259 & 2,148 \\
\hline & $F L_{j}^{W}$ & 2,155 & 2,543 & 2,233 & 2,277 & 2,365 & 2,589 & 2,241 \\
\hline & $e_{i}$ & 830,333 & 46,401 & 90,831 & $0,0 * *$ & 138,512 & $0,0 * * *$ & 0,777 \\
\hline \multirow{3}{*}{$\begin{array}{l}\text { Ulaştırma ve Depolama } \\
\text { Hizmetleri }\end{array}$} & $B L_{j}^{W}$ & 1,707 & 2,307 & 2,464 & 2,266 & 2,433 & 2,694 & 2,114 \\
\hline & $F L_{j}^{W}$ & 1,534 & 2,208 & 2,133 & 2,092 & 2,258 & 2,941 & 2,438 \\
\hline & $e_{i}$ & 35,833 & 2,720 & 7,997 & 5,864 & 2,897 & 2,700 & 1,673 \\
\hline \multirow[t]{3}{*}{ İnşaat ve İnşaat İşleri } & $B L_{j}^{W}$ & 1,251 & 1,157 & 1,109 & 1,360 & 1,601 & 0,988 & 2,134 \\
\hline & $F L_{j}^{W}$ & 0,671 & 0,530 & 0,509 & 0,709 & 0,825 & 0,496 & 1,491 \\
\hline & $e_{i}$ & $0,0 * * *$ & $0,0 * * *$ & 83,285 & $0,0 * * *$ & 13,042 & $0,0^{*}$ & 0,125 \\
\hline \multirow{3}{*}{$\begin{array}{l}\text { Bilgi ve İletişim Hizmetleri } \\
\text { Ille Mesleki, Bilimsel, Tek- } \\
\text { nik Hizmetler İle İdari ve } \\
\text { Destek Hizmetleri }\end{array}$} & $B L_{j}^{W}$ & 0,105 & 0,089 & 0,129 & 0,178 & 0,723 & 0,695 & 1,548 \\
\hline & $F L_{j}^{W}$ & 0,126 & 0,126 & 0,200 & 0,603 & 1,062 & 1,039 & 2,076 \\
\hline & $e_{i}$ & 2,125 & 1,475 & 1,784 & 0,749 & 1,348 & 0,393 & 0,276 \\
\hline \multirow{3}{*}{$\begin{array}{l}\text { Elektrik, Gaz, Buhar ve İk- } \\
\text { limlendirme İle Su Temini, } \\
\text { Kanalizasyon ve Atık Yöne- } \\
\text { timi Faaliyetleri }\end{array}$} & $B L_{j}^{W}$ & 0,256 & 0,207 & 0,466 & 0,358 & 0,414 & 0,556 & 1,471 \\
\hline & $F L_{j}^{W}$ & 0,362 & 0,289 & 0,776 & 0,681 & 0,756 & 0,987 & 2,064 \\
\hline & $e_{i}$ & 0,389 & 0,149 & 0,023 & 8,440 & 0,141 & 0,123 & 0,033 \\
\hline \multirow[t]{3}{*}{ Ana Metaller } & $B L_{j}^{W}$ & 0,887 & 0,583 & 1,076 & 1,073 & 1,089 & 1,037 & 1,052 \\
\hline & $F L_{j}^{W}$ & 1,473 & 0,876 & 1,590 & 1,536 & 1,740 & 1,612 & 1,048 \\
\hline & $e_{i}$ & 3,913 & 0,125 & 0,629 & 0,336 & 0,302 & 0,478 & 1,531 \\
\hline \multirow{3}{*}{$\begin{array}{l}\text { Kömür ve Petrol Ürünleri } \\
\text { (Plastik ve Kauçuk Dahil) }\end{array}$} & $B L_{j}^{W}$ & 0,778 & 1,114 & 1,236 & 0,892 & 0,895 & 0,670 & 1,064 \\
\hline & $F L_{j}^{W}$ & 1,075 & 1,630 & 2,071 & 1,235 & 1,269 & 0,911 & 1,206 \\
\hline & $e_{i}$ & 11,781 & 0,009 & 0,867 & 0,411 & 0,615 & 0,422 & 0,551 \\
\hline
\end{tabular}

Kaynak: TÜiK verileri kullanılarak yazar tarafından hesaplanmıştır. *ihracat $(X)=0$ iken ithalat $(M)>0$; ${ }^{* *}$ İhracat

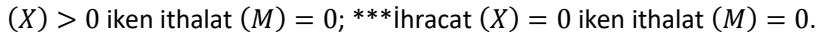

Gıda, içecek ve tütün ürünleri 1980 öncesinde ve 1980 sonrasında sürekli olarak yüksek geri ve düşük ileri bağlantıya sahiptir. Ancak 1980 sonrasında $e_{i}$ oranının giderek azaldığı ve 2012 yılı itibariyle 1,00 değerinin altına düştüğü görülmektedir. Tekstil, giyim eşyası, deri ve ilgili ürünler sektörü 1980 öncesinde yüksek geri ve düşük ileri bağlantı etkisine sahiptir ve $e_{i}$ oranı 
1,00'ın çok üzerindedir. 1980 sonrası ise 1985 ve 1998 yılında geri bağlantı etkisi de 1,00 değerinin altına düşmüştür. 2002 yılında ise bu sektör yüksek geri ve yüksek ileri bağlantı etkisi ile kilit sektör konumuna gelmiştir; ancak 2012 yılı itibariyle düşük ileri bağlantı ile sektör bu özelliğini yitirmiştir. 1980 sonrasında $e_{i}$ oranı azalmasına rağmen 1,00 değerinin çok üzerindedir.

Kereste, ağaç (mobilya dahil), kağıt ve ilgili ürünler sektörü hem 1980 öncesinde hem de 1980 sonrasında düşük geri ve ileri bağlantıya sahiptir ve 1973 yılı haricinde sürekli olarak ihraç ettiği çıktının üzerinde ara girdi ithal etmektedir. Basım ve kayıt hizmetleri sektörü, hem 1980 öncesinde hem de 1980 sonrasında düşük geri ve ileri bağlantıya sahiptir ve ihraç ettiği çıktının üzerinde ara girdi ithal etmektedir.

Plastik ve kauçuk dahil olmak üzere petrol ve kömür ürünleri üretimi sektörü, 1979 ve 1985 yıllarında kilit sektör konumundadır; ancak özellikle 1979 yılı olmak üzere söz konusu dönemde $e_{i}$ oranı 1,00'ın çok altındadır. 1985'den sonra 2012 yılında ilgili sektör yüksek geri ve ileri bağlantısı ile tekrar kilit sektör konumuna gelmiştir. Ancak kilit sektör olmasına rağmen ihraç ettiği çıktının üzerinde ara girdi ithal etmektedir.

Temel kimya ve eczacılık ürünleri sektörü, hem 1980 öncesinde hem de 1980 sonrasında kili sektör konumundadır. Ancak 2012 yılı itibariyle bu sektör ilk kez kilit sektör olma özelliğini yitirmiştir ve 1973 yılı haricinde dikkate alınan tüm yıllarda ihraç ettiği çıktının üzerinde ara girdi ithal etmektedir.

Ana metal sanayii, 1980 öncesinde kilit sektör konumunda değilken, 1980 sonrası sürekli olarak kilit sektör konumunda olmuştur. Üstelik 1973 yılından sonra ilk defa 2012 yılında ithal ettiği ara girdinin üzerinde çıktı ihraç etmiştir. Fabrikasyon metal ürünleri sanayii, analize dahil edilen tüm yıllarda düşük ileri bağlantı etkisine sahiptir. Yani metal ürünleri sanayii diğer sektörleri yeteri kadar besleyememektedir. Bunun yanında ilgili sektör 1980 öncesindeki her iki dönemde de $(1973,1979)$ yüksek geri bağlantıya sahiptir. 1980 sonrasında ise 1998 yılı itibariyle fabrikasyon metal ürünleri sanayii düşük geri ve düşük ileri bağlantı etkisine sahiptir. Bu sektörle ilgili olumlu gelişme ise 2012 yılı itibariyle $e_{i}$ oranı 1,00'ın üzerine çıkmış olmasıdır.

Bilgisayar, elektrikli ve optik ürünler, elektrikli teçhizat, makine ve ekipmanlar ile bunların bakım, onarım ve kurulum hizmetleri sektörü 1973 - 2012 döneminde yalnızca 1998 ve 2002 yıllarında kilit sektör konumuna gelmiştir. 2002 yılında kilit konumda olan ilgili sektör, 2012 yılında bu özelliğini yitirmiştir; ancak bu sektör 2012 yılında ilk kez kullandığı ithal ara girdi miktarından fazla çıktı ihraç etmiştir.

Motorlu kara taşıtları, römorklar ile diğer ulaşım araçları imalatı sektörü, dikkate alınan hiçbir dönemde kilit sektör konumuna gelememiştir, bu sektörde iki dikkate değer değişim göze çarpmaktadır. Birincisi 1998 yılında sektörün geri bağlantısı ilk kez ve tek olmak üzere 1,00'ın üzerine çıkmıştır. İkincisi, sektörün ihraç ettiği çıktı miktarı ilk kez ve tek olmak üzere ithal ettiği ara girdi miktarının üzerine çıkmıştır. Elektrik, gaz, buhar ve iklimlendirme ile su temini, kanalizasyon ve atık yönetimi sektörü, yalnızca 2012 yılı itibariyle kilit sektör konumuna gelebilmiştir. Ancak bu sektörün net ihracat yaratma yeteneği oldukça düşüktür.

İnşaat sektörü, genel olarak yüksek geri, düşük ileri bağlantı etkisine sahiptir. Ancak bu sektör ilk kez 2012 yılı itibariyle kilit sektör konumuna gelmiştir. Ancak büyük oranda ticarete konu olmayan mal üreten bu sektörün aynı zamanda yoğun olarak ithal ara girdi kullanmaya başladığı da görülmektedir. Öyle ki 2012 yılı için $e_{i}$ oranı 0,125'tir. 
Toptan ve perakende ticaret sektörü 2002 yılı hariç analize dahil edilen yılların tamamında kilit sektör konumundadır. 1973 - 1985 arası dönem ve 1998 yılı için $e_{i}$ oranı çok yüksek değerlerdedir. 1990 ve 2002 yıllarında hiç ithal ara girdi kullanmayan sektör, ihracat yapabilmiştir. Ancak sektörün ihracat performansı konusundaki bu özelliğini 2012 yılı itibariyle yitirdiği görülmektedir. Öyle ki bu yıl için $e_{i}$ oranı 0,777 olarak hesaplanmıştır.

Ulaştırma ve depolama hizmetleri sektörü 1973 - 2012 arasında analize dahil edilen tüm yıllar için yüksek geri ve ileri bağlantı ile kilit sektör konumundadır. Üstelik bu sektör yine analize dahil edilen tüm yıllar için kullandığı ithal ara girdiden daha fazla çıktı ihraç etmektedir. Konaklama ve yiyecek hizmetleri analize dahil edilen tüm yıllar için düşük geri ve ileri bağlantıya sahiptir. 2012 yılı itibariyle sektör ithal ettiği ara girdiden daha fazla çıktı ihraç etme özelliğini de yitirmiştir. Bilgi ve iletişim hizmetleri ile mesleki, bilimsel, teknik hizmetler ile idari ve destek hizmetleri sektörü yalnızca 2012 yılı itibariyle kilit sektör konumundadır. Ancak bu sektör 2012 yılı itibariyle yıllar içerisindeki en düşük $e_{i}$ oranına $(0,276)$ sahiptir.

Finans ve sigorta hizmetleri yalnızca 1998 yılında kilit sektör konumuna gelmiştir. Sektör 1990 yılı ve sonrasında sürekli olarak kullandığı ithal ara girdiden daha yüksek çıktı ihraç etmektedir. Gayrimenkul hizmetleri sektörü 2002 yılı ve sonrasında kilit sektör konumuna gelmiştir. Ancak bu sektörün 1979 ve 1998 yılları haricinde ihracat yeteneğinin olmadığı da görülmektedir. Kamu yönetimi, savunma ile sosyal güvenlik hizmetleri 1980 öncesinde kilit sektör konumunda iken, 1980 sonrası bu özelliğini yitirmiştir. Aynı zamanda bu sektörün ihracat yeteneğinin olmadığı da görülmektedir. Eğitim hizmetleri, insan sağlığı ve sosyal hizmetler ile kültür, sanat, eğlence ve spor hizmetleri 1973, 1979, 1985 ve 1990 girdi - çıktı tabloları için tek bir başlık altında yer aldığı için Ek Tablo 2 ve Ek Tablo 3'de aynı değerleri içerecek biçimde kalın çerçeve içerisinde gösterilmektedir. Ancak ayrı ayrı değerlendirilebilecek 1998, 2002 ve 2012 yılları için de bu sektörlerin tamamının düşük geri ve düşük ileri bağlantıya sahip olduğu görülmektedir.

\section{Sonuç ve Değerlendirme}

Bir ekonominin üretim yapısı, söz konusu üretim yapısının hangi sektörler arasındaki girdi alış - verişinde yoğunlaştığı, hangi sektörlerin ithal ara girdiye bağımlı olduğu gibi konuların analizinde girdi - çıktı yöntemi baz alınarak geliştirilen bağlantı analizleri kullanılmaktadır. Öyle ki bu analizlerin temeli Quensay (1758)'e ve Leontief (1936)'ya kadar uzanmaktadır. Rasmussen (1956) ve Chenery ve Watanabe (1958)'den sonra ise sektörel bağlantı analizleri ile ilgili geniş bir literatür olduğu görülmektedir.

Türkiye ekonomisi ile ilgili literatüre bakıldığında sektörel bağlantı analizlerinin uzun vadeli olmadığı, uzun vadeli olanların ise ayrıştırma analizleri dikkate alınarak yapılmadığı görülmektedir. Öyle ki, 24 Ocak 1980 kararlarının o tarihten günümüze Türkiye'nin üretim yapısına ve sektörlerin ithal ara girdi kullanımına olan etkisi henüz tam olarak ortaya koyulmamıştır. Bu çalışma literatürdeki söz konusu eksikliği gidermeye yönelik yapılmıştır. Bu amaçla öncelikle TÜiK tarafından yayımlanan tüm veriler ortak bir sınıflama baz alınarak toplulaştırılmış, toplulaştırılmış girdi - çıktı tabloları kullanılarak sektörler arasındaki bağlantı yapıları analiz edilmiştir. Bu analiz yapılırken tüm veriler için ithal - yurt içi üretim ara girdi ayrışması yapmak mümkün olmadığından, tüm yıllara ait veriler için sektörel bazda çıktı ihracatının ara malı ithalatını karşılama oranları da hesaplanmış ve bağlantı katsayıları ile birlikte değerlendirilmiştir.

Elde edilen bulgulara göre 24 Ocak 1980 kararları, birçok sektör için rekabet baskısı oluşturmuştur; öyle ki 1973 - 1979 arası dönemde dikkate alınan yirmi dört sektörün yalnızca dört 
tanesi ihraç ettiği çıktıdan daha fazla ara girdi ithal etmekteyken, 1985 - 2002 arası dönem için bu sayı dörtten yaklaşık on sekize yükselmiştir. 2012 yılı itibariyle ihraç ettiği çıktı miktarı, ithal ettiği ara girdi miktarından yüksek olan sektör sayısı on ikidir. 1980 öncesinde tarım ormancılık ve balıkçılık, temel kimyasal ürünlerle eczacılık ürünleri, toptan ve perakende ticaret, ulaştırma ve depolama hizmetleri ile kamu yönetimi savunma ve sosyal güvenlik hizmetleri yüksek geri ve ileri bağlantı ile kilit sektör konumundadır. Üstelik bu kilit sektörler çoğunlukla ithal ettiği ara girdiden daha fazla çıktı ihraç etmektedir. 24 Ocak 1980 kararlarından sonra tarım, ormancılık ve balıkçılık sektörü bağlantı etkilerindeki göreli önemini yitirmesine rağmen 1985 - 2012 döneminin tamamı için kilit sektör olma özelliğini korumuştur. Ancak bu sektörün liberalleşme politikalarıyla birlikte daha çok ara girdi kullandığı, 1990 ve 2002 yıllarında ise ihraç ettiğinden daha fazla ara girdi ithal ettiği görülmektedir. Tarım, ormancılık ve balıkçılık sektöründeki bu trend devam ettiği sürece, sektör hem kilit sektör olma özelliğini yitirecek, hem de net ihracat performansı negatife dönecektir. Temel kimya ve eczacılık ürünleri sektörü, 2012 yılı itibariyle ilk kez kilit sektör olma özelliğini yitirmiştir. 2002 yılında ilk kez kilit sektör olan tekstil ve giyim eşyası sektörü, 2012 yılı itibariyle bu özelliğini yitirmiştir. Ana metal sanayii, 1980 öncesi kilit sektör değilken, 1980 sonrasında sürekli olarak kilit sektör konumundadır. Üstelik ithal ara girdi kullanımından daha fazla ürün ihraç etmektedir. Bilgisayarlı, elektrikli ve optik ürünler yalnızca 1998 ve 2002 yıllarında kilit sektör konumunda iken, 2012 yılında bu özelliğini yitirmiştir. Ancak yine ilk kez 2012 yılında kullandığı ithal ara girdiden daha fazla çıktı ihraç etmiştir.

İnşaat sektörüne ayrı bir parantez açmak gerekmektedir. Öyle ki bu sektör 2012 yılında ilk kez kilit sektör konumuna gelmiştir. Bu durum diğer sektörlerden yoğun olarak beslenen ve diğer sektörleri yoğun olarak besleyen inşaat sektörünün ara girdisini nasıl temin ettiğinin analizini de ön plana çıkarmaktadır. Ancak $e_{i}$ oranları da dikkate alındığında bu sektörün ya hiç çıktı ihraç etmediği, ya da ihraç ettiği çıktıların ithal ettiği ara girdilerin çok üzerinde olduğu görülmektedir.

Toptan ve perakende ticaret 2002 yılı haricinde sürekli olarak kilit sektör konumundadır; ancak sektör 2012 yılında ilk kez ihraç ettiği çıktı miktarından daha fazla ara malı ithal etmiştir. Bilgi ve iletişim hizmetleri ile mesleki, bilimsel, teknik hizmetler ile idari ve destek hizmetleri ilk kez 2012 yılında kilit sektör konumuna gelmiştir. Gayrimenkul hizmetleri de 2002 yılı ve sonrasında kilit sektör konumuna gelmiştir ancak bu sektörün ihracat yeteneğinin olmadığı görülmektedir.

Bütün bu veriler dikkate alındığında, 1980 sonrasında hem kilit sektör konumuna gelen, hem de ihracat yeteneği kullandığı ithal ara girdiye göre artan tek sektörün ana metal sanayii olduğu görülmektedir. Bu nedenle yatırımların bu sektöre yoğunlaştırılması yararlı olacaktır. Bunun yanında 2012 yılı itibariyle kilit sektör konumunda olan ve ithal ettiği ara girdi miktarından fazla çıktı ihraç eden tarım, balıkçılık ve ormancılık sektörü ile ulaştırma ve depolama hizmetleri sektörüne de yatırım önceliği verilmelidir. Bilgisayarlı, elektrikli ve optik ürünlerle, elektrikli teçhizat, makine ve ekipmanlar sektörü yalnızca 2002 yılında kilit konuma gelmiştir. Bu nedenle 2012 yılı ihracat performansı ile 2002 yılındaki bağlantı performansının birlikte yakalanabilmesi için gerekli planlamanın yapılması, yüksek teknolojili ürünler üreten bu sektör için büyük önem arz etmektedir. Bunların yanında ihracat yeteneği olmayan, üstelik yoğun olarak ithal ara girdi kullanan inşaat sektörünün kilit konuma gelmesi önemle üzerinde durulması gereken bir konudur. Üretim yapısını sürekli olarak ara girdi ithal edip, hiç çıktı ihraç edemeyen sektörler üzerine kuran bir ekonominin uzun vadede dış şoklara karşı kırılgan bir yapıya geleceği unutulmamalıdır. 


\section{Eskişehir Osmangazi Üniversitesi IïB Dergisi}

\section{Kaynaklar}

Andreosso-O'Callaghan, B. and Yue, Guoqiang (2004), “Intersectoral Linkages and Key Sectors In China 1987-1997-An Application of Input-Output Linkage Analysis", Asian Economic Journal, Vol.18, No. 2.

Atan, Sibel (2011), "Türkiye'deki Sektörel Bağlantı Yapısının Girdi - Çıktı Yaklaşımı İle İncelenmesi: Yurtiçi Üretim ve İthal Ara Girdi Ayrıştırması", Ekonomik Yaklaşım Dergisi, C. 22, S. 80, 59 - 78.

Ayaş, Necla (2016), "Türkiye Ekonomisinde Hizmetler Sektörünün Ekonomik Etkilerinin Girdi Çıktı Modeli Ile Analizi", Afyon Kocatepe Üniversitesi Iktisadi ve Idari Bilimler Fakültesi Dergisi, C. 18, S. 2, 89-102.

Aydın, Serkan (2001), Türkiye İmalat Sanayinin Üretim Yapısı (1973 - 1990): Girdi - Çıktı Analizi, İstanbul Teknik Üniversitesi Fen Bilimleri Enstitüsü, Yayımlanmamış Yüksek Lisans Tezi.

Aydoğuş, Osman (1999), Girdi - Çıktı Modellerine Giriş, Gazi Kitabevi, Ankara.

Bocutoğlu, Ersan (1990), Endüstrilerarası Iktisat, Teori ve Türkiye Uygulamaları, KTÜ Basımevi, Trabzon.

Chenery, Hollis B. and Watanabe, Tsunehiko (1958), "International Comparisons Of The Structure Of Production", Econometrica, Vol.26, 487-521.

Çondur, Funda ve Evlimoğlu, Umut (2007), “Türkiye'de Madencilik Sektörünün Girdi-Çıktı Analizi Yöntemiyle İncelenmesi”, Sosyal Bilimler Dergisi, S. 17.

Drejer, Ina (2002), "Input-Output Based Measures of Interindustry Linkages Revisited- A Survey and Discussion", 14th International Conference on Input - Output Techniques, Austria.

Eren, Kasım (2004), “Input/Output Yöntemiyle Türkiye Ekonomisinin Bir Analizi”, Yönetim Dergisi, C. 15, S. 47, 27 - 51.

Ersungur, Mustafa Ş., ve Kızııtan, Alaattin (2008), “Türkiye Ekonomisinde Sektörlerarası Yapısal Bağınlaşma: Girdi-Çıktı Yöntemiyle Bir Uygulama", iktisadi ve Idari Bilimler Dergisi, C. 22, S. 2, 17 - 31.

Evans, Duane and Hoffenberg, Marvin (1954), Input - Output Computations, Proceeding of An Internaational Conference On Input - Output Analysis (Ed. T. Berna), New York, 53 - 57.

Gersak, Uros and Muhaj, Daniela (2016), Intersectoral Production Linkages In Slovenia: An Input-Output Analysis, Banka Slovenijes Surveys And Analyses 2/2016.

Gurgul, Henryk and Majdosz, Pawel (2005), "A Case Of The Transited Polish Economy”, Managing Global Transitions, Vol. 3, No. 1, 95-111.

Hawkins, Troy, Hendrickson, Chris, Higgins, Cortney, Matthews, Scott and Suh, Sangwon (2007), "A Mixed Unit Input - Output Model For Environmental Lifecycle Assessment and Material Flow Analysis", Environmental Science and Technology, Vol. 41, No. 3, $1024-1031$.

Hirschman, Albert O. (1958), The Strategy Of Economic Development, Yale University Press.

Humavindu, Michael N. and Stage, Jesper (2013), "Key Sectors Of The Namibian Economy", Journal Of Economic Structures, Vol. 2, No. 1.

Koutsoyiannis, Anna (2004), Modern Mikro iktisat (Çev. Muzaffer Sarımeşeli), Gazi Kitabevi.

McGilvray, James (1977), Linkages, Key Sectors and Development Strategy, Structure, System and Economic Policy (Ed. W. Leontief ), Cambridge University Press, $49-56$.

Miller, Ronald E. and Blair, Peter D. (2009), Input - Output Analysis Foundations and Extensions, Cambridge University Press, Second Edition.

Leontief, Wassily. (1936), "Quantitative Input and Output Relations in the Economic System and the United States." The Review of Economics and Statistics, Vol. 18, No. 3, $105-125$.

Öney, Erden (1980), iktisadi Planlama, Ankara Üniversitesi Siyasal Bilgiler Fakültesi Yayınları, Yayın No: 438.

Özkazanç, Önder (2006), Genel Denge ve Refah, İktisat Teorisi (Ed. Kemal Yıldırım, Mustafa Özer), Anadolu Üniversitesi Yayınları, , Eskişehir.

Rasmussen, Norregaard P. (1956), Studies In Inter-Sectoral Relations, Amsterdam: North Holland.

Reis, Hugo and Rua, Antonio (2006), An Input - Output Analysis: Linkages vs Leakages, Estudos e Documentos de Trabalho Working Papers, Banco De Portugal.

Quesnay, François (1758), Tableau Économique, 1st. Edition, https://www.taieb.net/auteurs/Quesnay/tableau.html (Erişim Tarihi: 12.05.2017).

Tanaka, Fujio John M. (2011), “Applications Of Leontief's Input-Output Analysis In Our Economy”, JAIRO. 
Temurshoev, Umed (2004), Key Sectors In The Kyrgyzstan Economy, CERGE - EI Discussion Paper Series, Discussion Paper No.2004 - 135.

Uğurlu, Ahmet Ali ve Tuncer, İsmail (2017), “Türkiye'de Sanayi ve Hizmet Sektörlerinin Büyüme ve İstihdama Katkıları: Girdi-Çıktı Analizi”, Dokuz Eylül Üniversitesi Iktisadi ve Idari Bilimler Fakültesi Dergisi, C. 32, S. 1.

Walras, Leon (1874), Éléments D'économie Politique Pure, http://www.gbv.de/dms/zbw/657540056.pdf (Erişim Tarihi: 15.05.2017).

West, Guy R. and Brown, Richard P. C. (2003), Structural Change, Intersectoral Linkages and Hollowing-Out In The Taiwanese Economy (1976 - 1994), http://www.uq.edu.au/economics/abstract/327.pdf (Erişim Tarihi: 02.06.2017). 
Eskişehir Osmangazi Üniversitesi iißBF Dergisi

EK

Ek Tablo 1: TüiK 1973, 1978, 1985, 1990, 1998, 2002 ve 2012 Girdi-Çıktı Tablolarının Toplulaştırılması

\begin{tabular}{|c|c|c|c|c|c|}
\hline & SEKTÖRLER & $\begin{array}{l}1973, \\
1978,1985 \\
\text { ve } 1990 \mathrm{G}- \\
\text { Ç }\end{array}$ & 1998 G-Ç & $\begin{array}{l}2002 \\
\text { G-Ç }\end{array}$ & 2012 G-Ç \\
\hline 1 & $\begin{array}{l}\text { Tarım, Ormancılık ve Balıkçılık Ürün- } \\
\text { leri }\end{array}$ & $\begin{array}{l}01,02,03, \\
04\end{array}$ & $\begin{array}{l}01,02,03, \\
04,05,06,07\end{array}$ & $\begin{array}{l}01,02, \\
03\end{array}$ & $\mathrm{~A} 01, \mathrm{~A} 02, \mathrm{~A} 03$ \\
\hline 2 & Madencilik ve Taş Ocakçılığı Ürünleri & $\begin{array}{l}05,06,07 \\
08,09,10\end{array}$ & $\begin{array}{l}08,09,10 \\
11,12\end{array}$ & $\begin{array}{l}04,05 \\
06,07 \\
08\end{array}$ & B \\
\hline 3 & Gıda, İçecekler ve Tütün Ürünleri & $\begin{array}{l}11,12,13 \\
14,15,16 \\
17,18,19\end{array}$ & $\begin{array}{l}13,14,15 \\
16,17,18 \\
19,20,21 \\
22,23,24,25\end{array}$ & 09,10 & $\mathrm{C} 10-\mathrm{C} 12$ \\
\hline 4 & $\begin{array}{l}\text { Tekstil, Giyim Eşyası, Deri ve İlgili } \\
\text { Ürünler }\end{array}$ & $\begin{array}{l}20,21,22 \\
23,24\end{array}$ & $\begin{array}{l}26,27,28 \\
29,30,31,32\end{array}$ & $\begin{array}{l}11,12 \\
13\end{array}$ & $\mathrm{C} 13-\mathrm{C} 15$ \\
\hline 5 & $\begin{array}{l}\text { Kereste, Ağaç (Mobilya Dahil), Kağıt } \\
\text { ve İlgili Ürünler }\end{array}$ & $\begin{array}{l}25,26,27 \\
49\end{array}$ & $33,34,35,67$ & $\begin{array}{l}14,15 \\
30\end{array}$ & C16, C17, C31 - C32 \\
\hline 6 & Basım ve Kayıt Hizmetleri & 28 & 36,37 & 16 & C18 \\
\hline 7 & $\begin{array}{l}\text { Kömür ve Petrol Ürünleri (Plastik ve } \\
\text { Kauçuk Dahil) }\end{array}$ & $\begin{array}{l}32,33,34, \\
35\end{array}$ & $38,44,45$ & 17,19 & C19, C22 \\
\hline 8 & $\begin{array}{l}\text { Temel Kimyasal Ürünler İle Eczacılık } \\
\text { Ürünleri (Metalik Olmayan Mineral } \\
\text { Ürünler Dahil) }\end{array}$ & $\begin{array}{l}29,30,31 \\
36,37,38\end{array}$ & $\begin{array}{l}39,40,41 \\
42,43,46 \\
47,48,49 \\
\end{array}$ & 18,20 & $\mathrm{C} 20, \mathrm{C} 21, \mathrm{C23}$ \\
\hline 9 & Ana Metaller & 39,40 & $50,51,52$ & 21 & $\mathrm{C} 24$ \\
\hline 10 & $\begin{array}{l}\text { Fabrikasyon Metal Ürünler (Makine } \\
\text { ve Ekipmanlar Hariç) }\end{array}$ & $41,42,43$ & 53,54 & 22 & $\mathrm{C} 25$ \\
\hline 11 & $\begin{array}{l}\text { Bilgisayar, Elektrikli ve Optik Ürün- } \\
\text { ler, Elektrikli Teçhizat, Diğer Makine } \\
\text { ve Ekipmanlar ile Bu Ekipmanların } \\
\text { Bakım, Kurulum, Onarım Hizmetleri }\end{array}$ & 44 & $\begin{array}{l}55,56,57 \\
58,59,60,61\end{array}$ & $\begin{array}{l}23,24 \\
25,26 \\
27\end{array}$ & $\mathrm{C} 26, \mathrm{C} 27, \mathrm{C} 28, \mathrm{C} 33$ \\
\hline 12 & $\begin{array}{l}\text { Motorlu Kara Taşıtları, Römorklar ve } \\
\text { Diğer Ulaşım Araçları }\end{array}$ & $\begin{array}{l}45,46,47, \\
48\end{array}$ & $\begin{array}{l}62,63,64 \\
65,66,68\end{array}$ & 28,29 & C29, C30 \\
\hline 13 & $\begin{array}{l}\text { Elektrik, Gaz, Buhar ve İklimlen- } \\
\text { dirme İle Su Temini, Kanalizasyon ve } \\
\text { Atık Yönetimi Faaliyetleri }\end{array}$ & 50,51 & $69,70,71$ & $\begin{array}{l}31,32, \\
33\end{array}$ & D36, E36, E37 - E39 \\
\hline 14 & İnşaat ve İnşaat İşleri & 52,53 & 72 & 34 & $\mathrm{~F}$ \\
\hline 15 & Toptan ve Perakende Ticaret & 54 & $73,74,75$ & $\begin{array}{l}35,36 \\
37\end{array}$ & G45, G46, G47 \\
\hline 16 & Ulaştırma ve Depolama Hizmetleri & $\begin{array}{l}56,57,58, \\
59\end{array}$ & $\begin{array}{l}78,79,80 \\
81,82\end{array}$ & $\begin{array}{l}39,40 \\
41,42 \\
43\end{array}$ & $\mathrm{H} 49$, H50, H51, H52, H53 \\
\hline
\end{tabular}


Aralık 2017, C. 12 , S. 3

\begin{tabular}{|c|c|c|c|c|c|}
\hline 17 & Konaklama ve Yiyecek Hizmetleri & 55 & 76,77 & 38 & 1 \\
\hline 18 & $\begin{array}{l}\text { Bilgi ve İletişim Hizmetleri Ille } \\
\text { Mesleki, Bilimsel, Teknik Hizmetler } \\
\text { ile İdari ve Destek Hizmetleri }\end{array}$ & 60 & $\begin{array}{l}83,87,88, \\
89,90\end{array}$ & $\begin{array}{l}48,49 \\
50,51\end{array}$ & $\begin{array}{l}J 58, \mathrm{J59}-\mathrm{J} 60, \mathrm{~J} 61, \mathrm{~J} 62- \\
\mathrm{J} 63, \mathrm{M} 69-\mathrm{M} 70, \mathrm{M} 71, \\
\mathrm{M} 72, \mathrm{M} 73, \mathrm{M} 74-\mathrm{M} 75 \\
\mathrm{~N} 77, \mathrm{~N} 78, \mathrm{~N} 79, \mathrm{~N} 80- \\
\mathrm{N} 82\end{array}$ \\
\hline 19 & Finans ve Sigorta Hizmetleri & 61 & 84,85 & $\begin{array}{l}44,45 \\
46\end{array}$ & K64, K65, K66 \\
\hline 20 & Gayrimenkul Hizmetleri & 64 & 86,97 & 47 & L68B, L68A \\
\hline 21 & $\begin{array}{l}\text { Kamu Yönetimi ve Savunma İle Sos- } \\
\text { yal Güvenlik Hizmetleri }\end{array}$ & 63 & 96 & 52 & 084 \\
\hline 22 & Eğitim Hizmetleri & \multirow{3}{*}{62} & 91 & 53 & P85 \\
\hline 23 & İnsan Sağlığı ve Sosyal Hizmetler & & 92,93 & 54,55 & Q86, Q87-Q88 \\
\hline 24 & $\begin{array}{l}\text { Kültür, Sanat, Eğlence ve Spor Hiz- } \\
\text { metleri Ile Diğer Hizmetler }\end{array}$ & & 94,95 & $\begin{array}{l}56,57 \\
58,59\end{array}$ & $\begin{array}{l}\text { R90 - R92, R93, S94, S95, } \\
\text { S96, T }\end{array}$ \\
\hline
\end{tabular}

Kaynak: Yazar tarafından hazırlanmıştır. 
Eskişehir Osmangazi Üniversitesi iißB Dergisi

Ek Tablo 2: Sektörlerin Ağırlıklandırılmış Toplam Geri Bağlantı Katsayıları $\left(B L_{j}^{W}\right)$ ve Sektörel Bazda Çıktı Ihracatının Ara Girdi ithalatını Karşılama Oranları $\left(e_{i}\right)$

\begin{tabular}{|c|c|c|c|c|c|c|c|c|c|}
\hline & SEKTÖRLER & & 1973 & 1979 & 1985 & 1990 & 1998 & 2002 & 2012 \\
\hline \multirow{2}{*}{1} & \multirow{2}{*}{$\begin{array}{l}\text { Tarım, Ormancılık ve } \\
\text { Balıkçılık Ürünleri }\end{array}$} & $B L_{j}^{W}$ & 4,555 & 4,297 & 2,771 & 2,918 & 2,286 & 1,771 & 1,384 \\
\hline & & $e_{i}$ & 3,608 & 5,806 & 1,309 & 0,963 & 1,027 & 0,946 & 1,059 \\
\hline \multirow{2}{*}{2} & \multirow{2}{*}{$\begin{array}{l}\text { Madencilik ve Taş } \\
\text { Ocakçılığı Ürünleri }\end{array}$} & $B L_{j}^{W}$ & 0,465 & 0,571 & 1,247 & 0,695 & 0,446 & 0,756 & 0,261 \\
\hline & & $e_{i}$ & 1,201 & 0,072 & 0,045 & 0,046 & 0,079 & 0,035 & 2,282 \\
\hline \multirow[t]{2}{*}{3} & \multirow{2}{*}{$\begin{array}{l}\text { Gıda, İçecekler ve Tü- } \\
\text { tün Ürünleri }\end{array}$} & $B L_{j}^{W}$ & 1,225 & 1,084 & 1,316 & 1,053 & 1,300 & 1,056 & 1,208 \\
\hline & & $e_{i}$ & 27,976 & 5,813 & 2,687 & 1,300 & 1,332 & 1,167 & 0,984 \\
\hline \multirow{2}{*}{4} & \multirow{2}{*}{$\begin{array}{l}\text { Tekstil, Giyim Eşyası, } \\
\text { Deri ve İlgili Ürünler }\end{array}$} & $B L_{j}^{W}$ & 1,088 & 1,291 & 0,991 & 1,463 & 0,827 & 1,667 & 1,234 \\
\hline & & $X e_{i}$ & 683,250 & 9,259 & 6,248 & 3,613 & 3,273 & 3,263 & 2,931 \\
\hline \multirow{2}{*}{5} & \multirow{2}{*}{$\begin{array}{l}\text { Kereste, Ağaç (Mo- } \\
\text { bilya Dahil), Kağıt ve } \\
\text { İlgili Ürünler }\end{array}$} & $B L_{j}^{W}$ & 0,454 & 0,551 & 0,558 & 0,707 & 0,433 & 0,588 & 0,625 \\
\hline & & $e_{i}$ & 51,500 & 0,289 & 0,622 & 0,208 & 0,485 & 0,717 & 0,961 \\
\hline \multirow{2}{*}{6} & \multirow{2}{*}{$\begin{array}{l}\text { Basım ve Kayıt Hiz- } \\
\text { metleri }\end{array}$} & $B L_{j}^{W}$ & 0,098 & 0,077 & 0,085 & 0,067 & 0,128 & 0,098 & 0,082 \\
\hline & & $e_{i}$ & 0,001 & 0,115 & 0,720 & 0,446 & 0,533 & 0,248 & 0,007 \\
\hline \multirow[b]{2}{*}{7} & \multirow{2}{*}{$\begin{array}{l}\text { Kömür ve Petrol Ürün- } \\
\text { leri (Plastik ve Kauçuk } \\
\text { Dahil) }\end{array}$} & $B L_{j}^{W}$ & 0,778 & 1,114 & 1,236 & 0,892 & 0,895 & 0,670 & 1,064 \\
\hline & & $e_{i}$ & 11,781 & 0,009 & 0,867 & 0,411 & 0,615 & 0,422 & 0,551 \\
\hline \multirow[b]{2}{*}{8} & \multirow{2}{*}{$\begin{array}{l}\text { Temel Kimyasal Ürün- } \\
\text { ler İle Eczacılık Ürün- } \\
\text { leri (Metalik Olmayan } \\
\text { Mineral Ürünler Dahil) }\end{array}$} & $B L_{j}^{W}$ & 1,192 & 1,136 & 1,434 & 1,344 & 1,477 & 1,588 & 0,956 \\
\hline & & $e_{i}$ & 6,173 & 0,097 & 0,268 & 0,262 & 0,258 & 0,256 & 0,937 \\
\hline \multirow{2}{*}{9} & \multirow{2}{*}{ Ana Metaller } & $B L_{j}^{W}$ & 0,887 & 0,583 & 1,076 & 1,073 & 1,089 & 1,037 & 1,052 \\
\hline & & $e_{i}$ & 3,913 & 0,125 & 0,629 & 0,336 & 0,302 & 0,478 & 1,531 \\
\hline \multirow{2}{*}{10} & \multirow{2}{*}{$\begin{array}{l}\text { Fabrikasyon Metal } \\
\text { Ürünler (Makine ve } \\
\text { Ekipmanlar Hariç) }\end{array}$} & $B L_{j}^{W}$ & 1,458 & 1,134 & 1,386 & 1,262 & 0,373 & 0,304 & 0,429 \\
\hline & & $e_{i}$ & 47,400 & 0,029 & 0,295 & 0,079 & 0,515 & 0,705 & 1,686 \\
\hline \multirow[b]{2}{*}{11} & \multirow[b]{2}{*}{$\begin{array}{l}\text { Bilgisayar, Elektrikli ve } \\
\text { Optik Ürünler, Elekt- } \\
\text { rikli Teçhizat, Makine } \\
\text { ve Ekipmanlar ile Bu } \\
\text { Ekipmanların Bakım, } \\
\text { Kurulum, Onarım Hiz- } \\
\text { metleri }\end{array}$} & $B L_{j}^{W}$ & 0,384 & 0,333 & 0,625 & 0,549 & 2,276 & 2,040 & 0,945 \\
\hline & & $e_{i}$ & 0,390 & 0,028 & 0,158 & 0,190 & 0,165 & 0,309 & 1,759 \\
\hline \multirow{2}{*}{12} & \multirow{2}{*}{$\begin{array}{l}\text { Motorlu Kara Taşıtları, } \\
\text { Römorklar ve Diğer } \\
\text { Ulaşım Araçları }\end{array}$} & $B L_{j}^{W}$ & 0,765 & 0,559 & 0,686 & 0,680 & 1,207 & 0,753 & 0,627 \\
\hline & & $e_{i}$ & 0,353 & 0,106 & 0,136 & 0,118 & 0,349 & 0,847 & 1,824 \\
\hline 13 & & $B L_{j}^{W}$ & 0,256 & 0,207 & 0,466 & 0,358 & 0,414 & 0,556 & 1,471 \\
\hline
\end{tabular}




\begin{tabular}{|c|c|c|c|c|c|c|c|c|c|}
\hline & $\begin{array}{l}\text { Elektrik, Gaz, Buhar ve } \\
\text { İlimlendirme İle Su } \\
\text { Temini, Kanalizasyon } \\
\text { ve Atık Yönetimi Faali- } \\
\text { yetleri }\end{array}$ & $e_{i}$ & 0,389 & 0,149 & 0,023 & 8,440 & 0,141 & 0,123 & 0,033 \\
\hline \multirow{2}{*}{14} & \multirow{2}{*}{ İnşaat ve İnşaat İşleri } & $B L_{j}^{W}$ & 1,251 & 1,157 & 1,109 & 1,360 & 1,601 & 0,988 & 2,134 \\
\hline & & $e_{i}$ & $0,0 * * *$ & $0,0 * * *$ & 83,285 & $0,0 * * *$ & 13,042 & $0,0^{*}$ & 0,125 \\
\hline \multirow{2}{*}{15} & \multirow{2}{*}{$\begin{array}{l}\text { Toptan ve Perakende } \\
\text { Ticaret }\end{array}$} & $B L_{j}^{W}$ & 1,808 & 2,005 & 2,006 & 2,066 & 2,113 & 2,259 & 2,148 \\
\hline & & $e_{i}$ & 830,333 & 46,401 & 90,831 & $0,0 * *$ & 138,512 & $0,0^{* * *}$ & 0,777 \\
\hline \multirow{2}{*}{16} & \multirow{2}{*}{$\begin{array}{l}\text { Ulaştırma ve Depo- } \\
\text { lama Hizmetleri }\end{array}$} & $B L_{j}^{W}$ & 1,707 & 2,307 & 2,464 & 2,266 & 2,433 & 2,694 & 2,114 \\
\hline & & $e_{i}$ & 35,833 & 2,720 & 7,997 & 5,864 & 2,897 & 2,700 & 1,673 \\
\hline \multirow{2}{*}{17} & \multirow{2}{*}{$\begin{array}{l}\text { Konaklama ve Yiyecek } \\
\text { Hizmetleri }\end{array}$} & $B L_{j}^{W}$ & 0,436 & 0,482 & 0,295 & 0,563 & 0,691 & 0,460 & 0,645 \\
\hline & & $e_{i}$ & 42,793 & 0,562 & 2,717 & 2,891 & 4,372 & $0,0^{* * *}$ & 0,412 \\
\hline \multirow[b]{2}{*}{18} & \multirow{2}{*}{$\begin{array}{l}\text { Bilgi ve İletişim Hiz- } \\
\text { metleri İle Mesleki, Bi- } \\
\text { limsel, Teknik Hizmet- } \\
\text { ler İle İdari ve Destek } \\
\text { Hizmetleri }\end{array}$} & $B L_{j}^{W}$ & 0,105 & 0,089 & 0,129 & 0,178 & 0,723 & 0,695 & 1,548 \\
\hline & & $e_{i}$ & 2,125 & 1,475 & 1,784 & 0,749 & 1,348 & 0,393 & 0,276 \\
\hline \multirow{2}{*}{19} & \multirow{2}{*}{$\begin{array}{l}\text { Finans ve Sigorta Hiz- } \\
\text { metleri }\end{array}$} & $B L_{j}^{W}$ & 0,490 & 0,380 & 0,389 & 0,484 & 1,190 & 0,780 & 0,538 \\
\hline & & $e_{i}$ & 6,375 & 0,964 & 0,310 & 24,955 & 1,364 & 1,150 & 1,498 \\
\hline \multirow{2}{*}{20} & \multirow{2}{*}{$\begin{array}{l}\text { Gayrimenkul Hizmet- } \\
\text { leri }\end{array}$} & $B L_{j}^{W}$ & 0,620 & 0,650 & 0,667 & 0,465 & 0,489 & 1,334 & 1,326 \\
\hline & & $X e_{i}$ & $0,0 * * *$ & 1,466 & $0,0^{* * *}$ & $0,0 * * *$ & 13,565 & $0,0 * * *$ & $0,0 * *$ \\
\hline \multirow{2}{*}{21} & \multirow{2}{*}{$\begin{array}{l}\text { Kamu Yönetimi ve Sa- } \\
\text { vunma İle Sosyal Gü- } \\
\text { venlik Hizmetleri }\end{array}$} & $B L_{j}^{W}$ & 1,361 & 1,459 & 0,592 & 0,883 & 0,916 & 0,850 & 0,701 \\
\hline & & $e_{i}$ & $0,0 * * *$ & $0,0 * * *$ & $0,0^{* * *}$ & $0,0 * * *$ & 0,384 & 0,238 & $0,0 * *$ \\
\hline \multirow{2}{*}{22} & \multirow{2}{*}{ Eğitim Hizmetleri } & $B L_{j}^{W}$ & 0,617 & 0,536 & 0,475 & 0,674 & 0,126 & 0,403 & 0,541 \\
\hline & & $e_{i}$ & 10,964 & 0,414 & 1,254 & 1,716 & 0,147 & $0,0^{* * *}$ & $0,0 * *$ \\
\hline \multirow{2}{*}{23} & \multirow{2}{*}{$\begin{array}{l}\text { İnsan Sağlığı ve Sosyal } \\
\text { Hizmetler }\end{array}$} & $B L_{j}^{W}$ & 0,617 & 0,536 & 0,475 & 0,674 & 0,365 & 0,281 & 0,553 \\
\hline & & $e_{i}$ & 10,964 & 0,414 & 1,254 & 1,716 & 0,652 & 13,833 & 0,028 \\
\hline \multirow[b]{2}{*}{24} & \multirow{2}{*}{$\begin{array}{l}\text { Kültür, Sanat, Eğlence } \\
\text { ve Spor Hizmetleri İle } \\
\text { Diğer Hizmetler }\end{array}$} & $B L_{j}^{W}$ & 0,617 & 0,536 & 0,475 & 0,674 & 0,190 & 0,370 & 0,415 \\
\hline & & $e_{i}$ & 10,964 & 0,414 & 1,254 & 1,716 & 0,604 & 0,427 & 0,005 \\
\hline
\end{tabular}

Kaynak: TÜiK verileri kullanılarak yazar tarafından hesaplanmıştır. *ihracat $(X)=0$ iken ithalat $(M)>0$; ** ihracat $(X)>0$ iken ithalat $(M)=0 ; * *$ ihracat $(X)=0$ iken ithalat $(M)=0$. 
Eskişehir Osmangazi Üniversitesi ïBß Dergisi

Ek Tablo 3: Sektörlerin Ağırlıklandırılmış Toplam Ileri Bağlantı Katsayıları $\left(F L_{j}^{W}\right)$ ve Sektörel Bazda Çıktı Ihracatının Ara Girdi Ithalatını Karşılama Oranları $\left(e_{i}\right)$

\begin{tabular}{|c|c|c|c|c|c|c|c|c|c|}
\hline & SEKTÖRLER & & 1973 & 1979 & 1985 & 1990 & 1998 & 2002 & 2012 \\
\hline \multirow{2}{*}{1} & \multirow{2}{*}{$\begin{array}{l}\text { Tarım, Ormancılık ve Balık- } \\
\text { çılık Ürünleri }\end{array}$} & $F L_{j}^{W}$ & 4,679 & 4,040 & 2,535 & 2,628 & 2,187 & 1,707 & 1,516 \\
\hline & & $e_{i}$ & 3,608 & 5,806 & 1,309 & 0,963 & 1,027 & 0,946 & 1,059 \\
\hline \multirow{2}{*}{2} & \multirow{2}{*}{$\begin{array}{l}\text { Madencilik ve Taş Ocakçılığı } \\
\text { Ürünleri }\end{array}$} & $F L_{j}^{W}$ & 0,794 & 0,923 & 2,105 & 1,059 & 0,931 & 1,198 & 0,414 \\
\hline & & $e_{i}$ & 1,201 & 0,072 & 0,045 & 0,046 & 0,079 & 0,035 & 2,282 \\
\hline \multirow[t]{2}{*}{3} & \multirow{2}{*}{$\begin{array}{l}\text { Gıda, İçecekler ve Tütün } \\
\text { Ürünleri }\end{array}$} & $F L_{j}^{W}$ & 0,830 & 0,741 & 0,841 & 0,808 & 0,950 & 0,685 & 0,896 \\
\hline & & $e_{i}$ & 27,976 & 5,813 & 2,687 & 1,300 & 1,332 & 1,167 & 0,984 \\
\hline \multirow{2}{*}{4} & \multirow{2}{*}{$\begin{array}{l}\text { Tekstil, Giyim Eşyası, Deri } \\
\text { ve İlgili Ürünler }\end{array}$} & $F L_{j}^{W}$ & 0,768 & 0,902 & 0,659 & 0,875 & 0,564 & 1,209 & 0,996 \\
\hline & & $X e_{i}$ & 683,250 & 9,259 & 6,248 & 3,613 & 3,273 & 3,263 & 2,931 \\
\hline \multirow{2}{*}{5} & \multirow{2}{*}{$\begin{array}{l}\text { Kereste, Ağaç (Mobilya Da- } \\
\text { hil), Kağıt ve İlgili Ürünler }\end{array}$} & $F L_{j}^{W}$ & 0,484 & 0,545 & 0,522 & 0,628 & 0,524 & 0,568 & 0,559 \\
\hline & & $e_{i}$ & 51,500 & 0,289 & 0,622 & 0,208 & 0,485 & 0,717 & 0,961 \\
\hline \multirow{2}{*}{6} & \multirow{2}{*}{ Basım ve Kayıt Hizmetleri } & $F L_{j}^{W}$ & 0,072 & 0,062 & 0,064 & 0,115 & 0,153 & 0,140 & 0,134 \\
\hline & & $e_{i}$ & 0,001 & 0,115 & 0,720 & 0,446 & 0,533 & 0,248 & 0,007 \\
\hline \multirow{2}{*}{7} & \multirow{2}{*}{$\begin{array}{l}\text { Kömür ve Petrol Ürünleri } \\
\text { (Plastik ve Kauçuk Dahil) }\end{array}$} & $F L_{j}^{W}$ & 1,075 & 1,630 & 2,071 & 1,235 & 1,269 & 0,911 & 1,206 \\
\hline & & $e_{i}$ & 11,781 & 0,009 & 0,867 & 0,411 & 0,615 & 0,422 & 0,551 \\
\hline \multirow[b]{2}{*}{8} & \multirow{2}{*}{$\begin{array}{l}\text { Temel Kimyasal Ürünler İle } \\
\text { Eczacılık Ürünleri (Metalik } \\
\text { Olmayan Mineral Ürünler } \\
\text { Dahil) }\end{array}$} & $F L_{j}^{W}$ & 1,240 & 1,367 & 1,405 & 1,868 & 1,879 & 1,889 & 1,118 \\
\hline & & $e_{i}$ & 6,173 & 0,097 & 0,268 & 0,262 & 0,258 & 0,256 & 0,937 \\
\hline \multirow{2}{*}{9} & \multirow{2}{*}{ Ana Metaller } & $F L_{j}^{W}$ & 1,473 & 0,876 & 1,590 & 1,536 & 1,740 & 1,612 & 1,048 \\
\hline & & $e_{i}$ & 3,913 & 0,125 & 0,629 & 0,336 & 0,302 & 0,478 & 1,531 \\
\hline \multirow{2}{*}{10} & \multirow{2}{*}{$\begin{array}{l}\text { Fabrikasyon Metal Ürünler } \\
\text { (Makine ve Ekipmanlar Ha- } \\
\text { riç) }\end{array}$} & $F L_{j}^{W}$ & 0,923 & 0,748 & 0,731 & 0,768 & 0,424 & 0,327 & 0,397 \\
\hline & & $e_{i}$ & 47,400 & 0,029 & 0,295 & 0,079 & 0,515 & 0,705 & 1,686 \\
\hline \multirow[b]{2}{*}{11} & \multirow{2}{*}{$\begin{array}{l}\text { Bilgisayar, Elektrikli ve Op- } \\
\text { tik Ürünler, Elektrikli Teçhi- } \\
\text { zat, Makine ve Ekipmanlar } \\
\text { ile Bu Ekipmanların Bakım, } \\
\text { Kurulum, Onarım Hizmet- } \\
\text { leri }\end{array}$} & $F L_{j}^{W}$ & 0,244 & 0,275 & 0,427 & 0,501 & 1,458 & 1,429 & 0,728 \\
\hline & & $e_{i}$ & 0,390 & 0,028 & 0,158 & 0,190 & 0,165 & 0,309 & 1,759 \\
\hline \multirow{2}{*}{12} & \multirow{2}{*}{$\begin{array}{l}\text { Motorlu Kara Taşıtları, Rö- } \\
\text { morklar ve Diğer Ulaşım } \\
\text { Araçları }\end{array}$} & $F L_{j}^{W}$ & 0,721 & 0,553 & 0,562 & 0,418 & 0,692 & 0,504 & 0,417 \\
\hline & & $e_{i}$ & 0,353 & 0,106 & 0,136 & 0,118 & 0,349 & 0,847 & 1,824 \\
\hline \multirow[b]{2}{*}{13} & \multirow{2}{*}{$\begin{array}{l}\text { Elektrik, Gaz, Buhar ve İk- } \\
\text { limlendirme İle Su Temini, } \\
\text { Kanalizasyon ve Atık Yöne- } \\
\text { timi Faaliyetleri }\end{array}$} & $F L_{j}^{W}$ & 0,362 & 0,289 & 0,776 & 0,681 & 0,756 & 0,987 & 2,064 \\
\hline & & $e_{i}$ & 0,389 & 0,149 & 0,023 & 8,440 & 0,141 & 0,123 & 0,033 \\
\hline
\end{tabular}


Aralık 2017, C. 12 , S. 3

\begin{tabular}{|c|c|c|c|c|c|c|c|c|c|}
\hline \multirow{2}{*}{14} & \multirow{2}{*}{ İnşaat ve İnşaat İşleri } & $F L_{j}^{W}$ & 0,671 & 0,530 & 0,509 & 0,709 & 0,825 & 0,496 & 1,491 \\
\hline & & $e_{i}$ & $0,0 * * *$ & $0,0 * * *$ & 83,285 & $0,0 * * *$ & 13,042 & $0,0^{*}$ & 0,125 \\
\hline \multirow{2}{*}{15} & \multirow{2}{*}{$\begin{array}{l}\text { Toptan ve Perakende Tica- } \\
\text { ret }\end{array}$} & $F L_{j}^{W}$ & 2,155 & 2,543 & 2,233 & 2,277 & 2,365 & 2,589 & 2,241 \\
\hline & & $e_{i}$ & 830,333 & 46,401 & 90,831 & $0,0 * *$ & 138,512 & $0,0 * * *$ & 0,777 \\
\hline \multirow{2}{*}{16} & \multirow{2}{*}{$\begin{array}{l}\text { Ulaştırma ve Depolama Hiz- } \\
\text { metleri }\end{array}$} & $F L_{j}^{W}$ & 1,534 & 2,208 & 2,133 & 2,092 & 2,258 & 2,941 & 2,438 \\
\hline & & $e_{i}$ & 35,833 & 2,720 & 7,997 & 5,864 & 2,897 & 2,700 & 1,673 \\
\hline \multirow{2}{*}{17} & \multirow{2}{*}{$\begin{array}{l}\text { Konaklama ve Yiyecek Hiz- } \\
\text { metleri }\end{array}$} & $F L_{j}^{W}$ & 0,229 & 0,285 & 0,171 & 0,454 & 0,533 & 0,304 & 0,482 \\
\hline & & $X e_{i}$ & 42,793 & 0,562 & 2,717 & 2,891 & 4,372 & $0,0 * * *$ & 0,412 \\
\hline \multirow[b]{2}{*}{18} & \multirow{2}{*}{$\begin{array}{l}\text { Bilgi ve İletişim Hizmetleri } \\
\text { İle Mesleki, Bilimsel, Teknik } \\
\text { Hizmetler İle İdari ve Des- } \\
\text { tek Hizmetleri }\end{array}$} & $F L_{j}^{W}$ & 0,126 & 0,126 & 0,200 & 0,603 & 1,062 & 1,039 & 2,076 \\
\hline & & $e_{i}$ & 2,125 & 1,475 & 1,784 & 0,749 & 1,348 & 0,393 & 0,276 \\
\hline \multirow{2}{*}{19} & \multirow{2}{*}{ Finans ve Sigorta Hizmetleri } & $F L_{j}^{W}$ & 0,945 & 0,734 & 0,721 & 1,050 & 1,557 & 1,085 & 0,725 \\
\hline & & $e_{i}$ & 6,375 & 0,964 & 0,310 & 24,955 & 1,364 & 1,150 & 1,498 \\
\hline \multirow{2}{*}{20} & \multirow{2}{*}{ Gayrimenkul Hizmetleri } & $F L_{j}^{W}$ & 0,550 & 0,547 & 0,622 & 0,398 & 0,421 & 1,135 & 1,424 \\
\hline & & $e_{i}$ & $0,0 * * *$ & 1,466 & $0,0 * * *$ & $0,0 * * *$ & 13,565 & $0,0 * * *$ & $0,0 * *$ \\
\hline \multirow[b]{2}{*}{21} & \multirow{2}{*}{$\begin{array}{l}\text { Kamu Yönetimi ve Savunma } \\
\text { İle Sosyal Güvenlik Hizmet- } \\
\text { leri }\end{array}$} & $F L_{j}^{W}$ & 1,361 & 1,459 & 0,592 & 0,883 & 0,917 & 0,459 & 0,482 \\
\hline & & $e_{i}$ & $0,0^{* * *}$ & $0,0 * * *$ & $0,0 * * *$ & $0,0 * * *$ & 0,384 & 0,238 & $0,0 * *$ \\
\hline \multirow[b]{2}{*}{22} & \multirow[b]{2}{*}{ Eğitim Hizmetleri } & $F L_{j}^{W}$ & 0,765 & 0,616 & 0,532 & 0,413 & 0,084 & 0,295 & 0,462 \\
\hline & & $e_{i}$ & 10,964 & 0,414 & 1,254 & 1,716 & 0,147 & $0,0 * * *$ & $0,0 * *$ \\
\hline \multirow{2}{*}{23} & \multirow{2}{*}{$\begin{array}{l}\text { İnsan Sağlığı ve Sosyal Hiz- } \\
\text { metler }\end{array}$} & $F L_{j}^{W}$ & 0,765 & 0,616 & 0,532 & 0,413 & 0,255 & 0,164 & 0,373 \\
\hline & & $e_{i}$ & 10,964 & 0,414 & 1,254 & 1,716 & 0,652 & 13,833 & 0,028 \\
\hline \multirow[b]{2}{*}{24} & \multirow{2}{*}{$\begin{array}{l}\text { Kültür, Sanat, Eğlence ve } \\
\text { Spor Hizmetleri İle Diğer } \\
\text { Hizmetler }\end{array}$} & $F L_{j}^{W}$ & 0,765 & 0,616 & 0,532 & 0,413 & 0,200 & 0,328 & 0,315 \\
\hline & & $e_{i}$ & 10,964 & 0,414 & 1,254 & 1,716 & 0,604 & 0,427 & 0,005 \\
\hline
\end{tabular}

Kaynak: TÜiK verileri kullanılarak yazar tarafından hesaplanmıştır. *ihracat $(X)=0$ iken ithalat $(M)>0$; ** ihracat $(X)>0$ iken ithalat $(M)=0 ; * * *$ ihracat $(X)=0$ iken ithalat $(M)=0$. 
Eskişehir Osmangazi Üniversitesi IißBF Dergisi 